\title{
Mauritius: 2009 Article IV Consultation-Staff Report; Public Information Notice on the Executive Board Discussion; and Statement by the Executive Director for Mauritius
}

Under Article IV of the IMF's Articles of Agreement, the IMF holds bilateral discussions with members, usually every year. In the context of the 2009 Article IV consultation with Mauritius, the following documents have been released and are included in this package:

- $\quad$ The staff report for the 2009 Article IV consultation, prepared by a staff team of the IMF, following discussions that ended on October 31, 2009, with the officials of Mauritius on economic developments and policies. Based on information available at the time of these discussions, the staff report was completed on December 28, 2009. The views expressed in the staff report are those of the staff team and do not necessarily reflect the views of the Executive Board of the IMF.

- $\quad$ A Public Information Notice (PIN) summarizing the views of the Executive Board as expressed during its January 13, 2010 discussion of the staff report that concluded the Article IV consultation.

- $\quad$ A statement by the Executive Director for Mauritius.

The policy of publication of staff reports and other documents allows for the deletion of marketsensitive information.

\author{
Copies of this report are available to the public from \\ International Monetary Fund • Publication Services \\ $70019^{\text {th }}$ Street, N.W. • Washington, D.C. 20431 \\ Telephone: (202) 623-7430 • Telefax: (202) 623-7201 \\ E-mail: publications@imf.org Internet: http://www.imf.org
}

\section{International Monetary Fund Washington, D.C.}


INTERNATIONAL MONETARY FUND

MAURITIUS

\section{Staff Report for the 2009 Article IV Consultation}

Prepared by the Staff Representatives for the 2009 Consultation with Mauritius

(In consultation with other Departments)

Approved by Roger Nord and Aasim Husain

December 28, 2009

Consultation and Team. The 2009 Article IV consultation discussions with Mauritius were held in Port Louis October 19-31, 2009. The staff team comprised Mr. Ghosh (Head, RES), Mr. Köhler, Mr. Samake (both AFR), Mr. Tsangarides (RES), and Mr. Bastos (World Bank). The team met with Prime Minister, the Hon. Navinchandra Ramgoolam; the Minister of Finance and Economic Empowerment, Hon. Rama Sithanen; Central Bank Governor Rundheersing Bheenick; other senior government officials; representatives of the private sector; and the leader of the opposition.

2008 Article IV Consultation. Directors welcomed the revival of the Mauritian economy, spurred by the tax and business environment reforms adopted since 2006 that have helped reduce fiscal deficits and attract foreign direct investment. They encouraged the authorities to take steps to enhance labor market flexibility and improve the coverage and reliability of national statistics.

Policies. Mauritius has suffered from the fallout of the global financial crisis. The authorities' response was commendably prompt and comprehensive, including a temporary stimulus package of some 5 percent of GDP over the period July 2009December 2010. Monetary policy was also loosened; the key repo rate was cut by 250 b.p. and reserve requirements were reduced. A set of temporary and targeted measures were directed at job preservation. The banking system remains robust and has proved resilient. Structural reforms since 2006 have progressed well, but challenges remain.

Exchange rate system. Mauritius has accepted the obligations of Article VIII, Sections 2, 3, and 4. It maintains an exchange system free of restrictions on the making of payments and transfers for current international transactions.

Two working papers, on monetary policy transmission mechanism and balance sheet analysis for Mauritius, will be issued as companion papers to this report. 


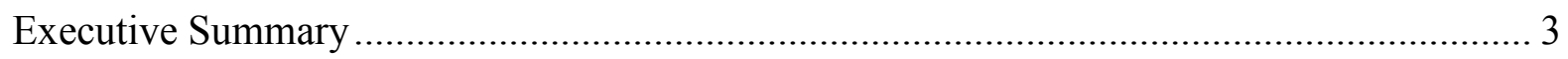

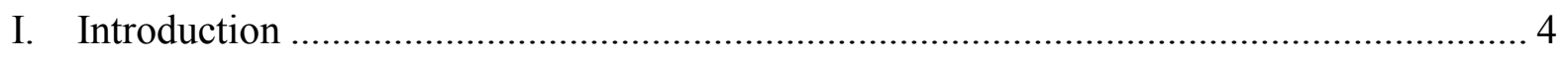

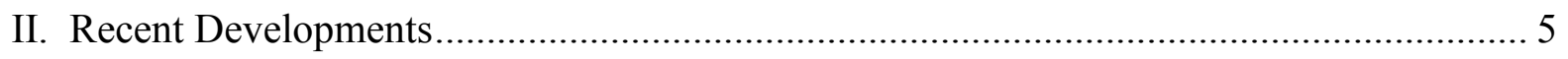

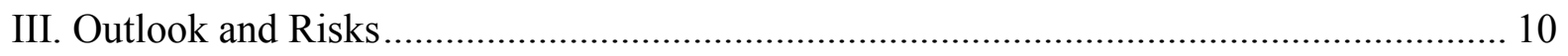

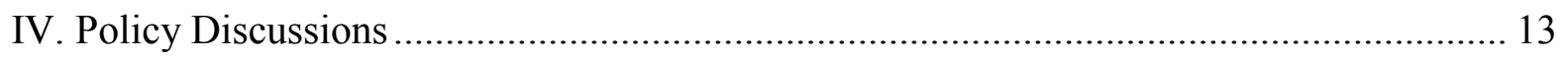

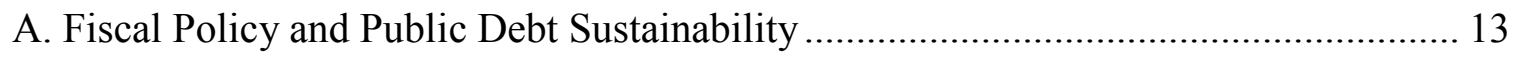

B. Monetary Policy and Framework ............................................................................ 15

C. Financial Sector, Structural Reforms, and Data Coverage...................................... 17

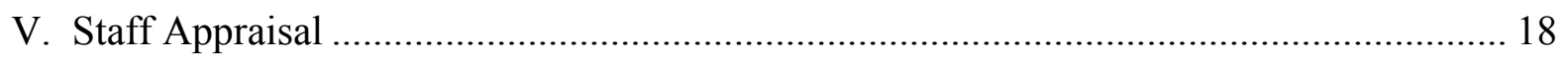

Figures

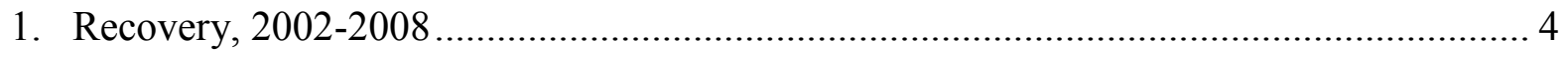

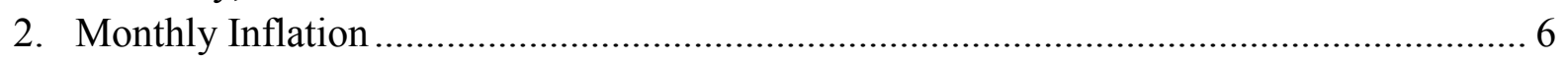

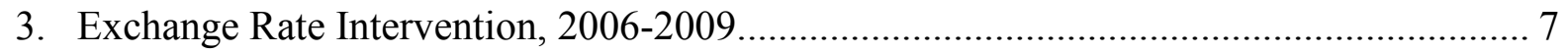

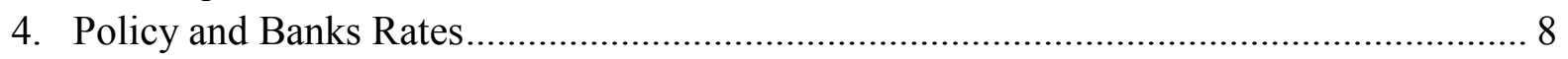

Chart

Macroeconomic Developments, 2006-2009 ................................................................... 9

Boxes

1. Reforms, 2006-2009 ........................................................................................... 5

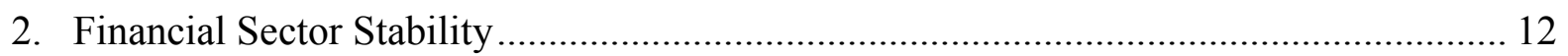

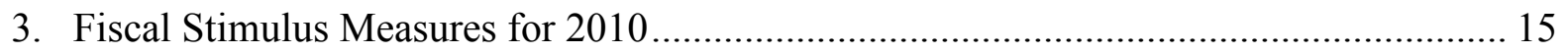

4. Monetary Policy Reaction Function .................................................................... 16

\section{Tables}

1. Selected Economic and Financial Indicators, 2005-2013 ........................................ 20

2. Summary of Central Government Finances, 2006/07-2011 ...................................... 21

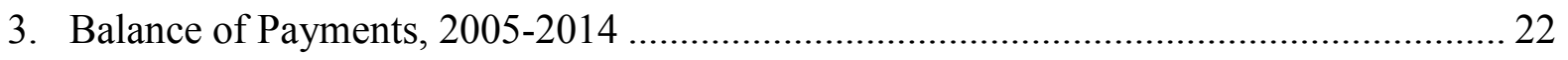

4. Depository Corporations Survey, December 2006-June 2009 .................................... 23

5. Financial Soundness Indicators for the Banking Sector, 2002-2009 ............................ 24

6. Indicators of Financial and External Vulnerability, 2005-2012 ............................... 25

\section{Appendix}

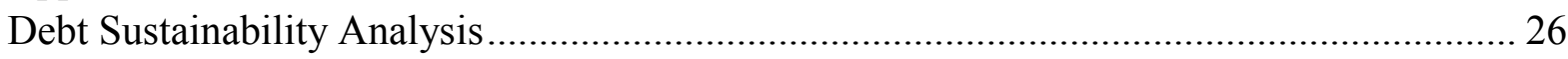




\section{EXECUTIVE SUMMARY}

Economic growth has slowed sharply in the wake of the global financial crisis, but is expected to rebound next year. Output growth slowed from 4.2 per year percent in 2008 to less than 2 percent in 2009 as key drivers of growth (tourism, textiles, and construction) contracted. Mauritius' growth prospects depend heavily on the global economy, especially the EU. Inflation has fallen to the low single digits as a result of lower global food and commodity prices and the slowdown of the domestic economy. The current account deficit has narrowed as lower imports have more than offset the contraction of external demand.

The authorities' policy response was commendably prompt and comprehensive, including a fiscal stimulus package of some 5 percent of GDP over the period July 2009December 2010. The package is well-targeted and temporary, intended to cushion the economy against the impact of the crisis. The government was prescient in having saved some 3 percent of GDP in special funds for such a rainy day. For its post-crisis strategy, the key challenge will be to resume fiscal consolidation without jeopardizing the recovery. Given the uncertain outlook, the government has rightly decided to keep some stimulus measures contingent; the 2010 deficit is now expected to be 4 $\frac{1}{2}$ percent of GDP.

Further fiscal consolidation is important to reduce risks inherent to a relatively high level of public debt. DSAs show that public and external debt should remain sustainable over the medium term. The 2008 Public Debt Management Act will serve to instill fiscal discipline and help ensure debt remains sustainable.

With inflationary pressures subdued, and the economic outlook uncertain, the monetary policy stance appears appropriate. In the wake of the crisis, the Monetary Policy Committee of the Bank of Mauritius (BoM) reduced the key Repo rate to 5.75 percent per year in successive steps and has kept it unchanged over the past few months pending further indication of the state of the economy. The BoM has refrained from intervention since December 2008, and the floating exchange rate has remained stable against the U.S. dollar.

The Mauritian banking system has withstood the impact of the global financial turmoil. Banks' conservative business practices, their strong initial balance sheets, and the "Mauritius Approach"- providing temporary financial relief to firms hit by the crises - have kept the financial system sound. Capital adequacy, liquidity, and profitability of the banking system remain sound, and the system appears resilient.

Measures to enhance efficiency in the public sector and to meet SDDS subscription requirements are well under way. Labor market reforms have been enacted, and service delivery and efficiency of the public sector is improving, especially in regard to social protection. The authorities are on track to improve the coverage of external statistics and to apply for SDDS subscription by mid-2010.

The authorities broadly agreed with the staff's assessment and recommendations. 


\section{INTRODUCTION}

1. Mauritius has achieved remarkable success since its independence in 1968, with one of the highest per capita incomes in Africa. Underpinning this performance have been macroeconomic and political stability, robust institutions, an efficient administration, a favorable regulatory environment, and a well-developed financial system. ${ }^{1}$ In 2005 , facing major external shocks (the phasing out of the Multi-Fiber Agreement and sharp reductions in EU sugar protocol prices), the government embarked on wide-ranging reforms that earned Mauritius the title of "best place to do business in Africa" from the World Bank in 2008 and 2009. Structural measures (Box 1) were accompanied by efforts to strengthen monetary and fiscal policy. ${ }^{2}$

2. The economy reacted favorably to the reforms

Figure 1: Mauritius' Recovery, $2002-2008$ initiated in 2005. Growth recovered to $6 \frac{1}{2}$ percent in 2007/08 (Figure 1) and foreign direct investment rose to unprecedented levelscomplementing a major restructuring of the sugar and textile industries and rapid growth in the offshore financial sector, which was driven by the activities of the Global Business Companies (GBC). While the latter have

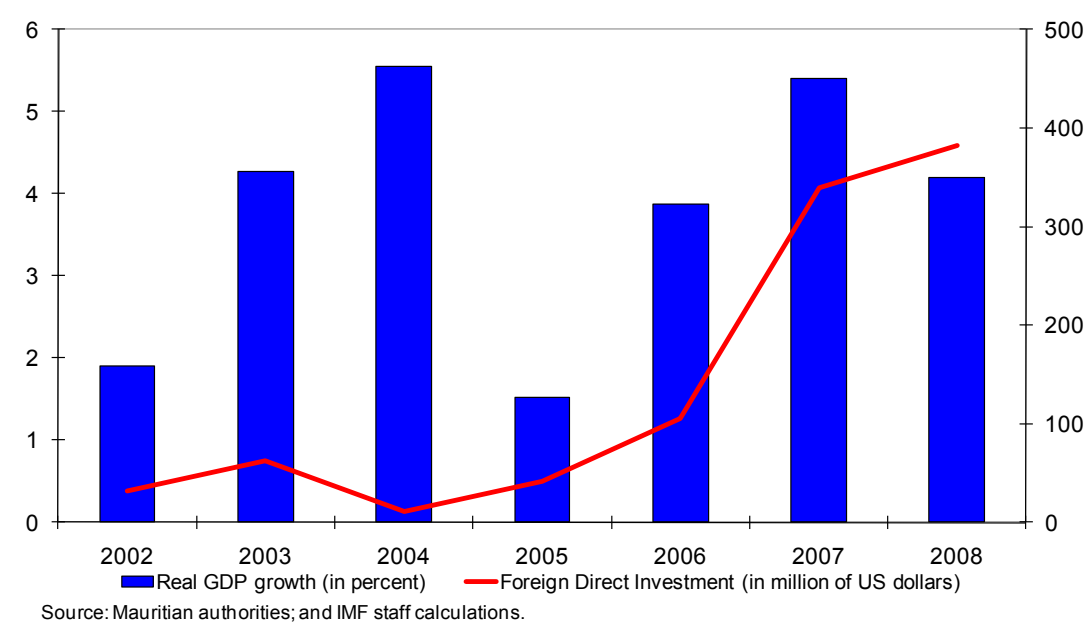
focused primarily on investments to India, Mauritius has also begun to position itself as a platform for investment from China and India to East Africa.

3. Like other emerging market economies (EMEs), Mauritius is now contending with the fallout of the global financial crisis - notably, the decline in demand for tourism and textile exports. The authorities have responded with a comprehensive policy package that includes fiscal stimulus, monetary easing, ensuring foreign exchange (FX) liquidity,

\footnotetext{
${ }^{1}$ See Sacerdoti, El-Masry, Khandelwal, and Yao, Mauritius: Challenges of Sustained Growth (IMF, 2005).

${ }^{2}$ Including a 15 percent flat tax rate, establishment of a central revenue authority, adoption of a fiscal consolidation strategy anchored in budgetary reforms (supported by Fund technical assistance), and a public debt law that stipulates reducing public debt to 50 percent of GDP by 2013 from its peak of 80 percent in 2003.
} 
strengthening the social safety net, and measures to facilitate workouts of private sector debt and to preserve jobs. ${ }^{3}$

\section{Box 1. Reforms, 2006-09}

Consolidating Fiscal Performance and Improving Public Sector Efficiency

- Fiscal rules implemented (current expenditure rule and public debt legislation)

- Performance-based budgeting, public management systems, and medium-term expenditure frameworks introduced

- Tax system revamped (single flat tax on personal and corporate income)

- New procurement legislation

- Reforms in the parastatal sector launched

Enhancing Competitiveness

- Tariff duties reduced

- Regulations for export-processing zone (EPZ) and non-EPZ firms unified

- Air access liberalized

- Immigration restrictions eased

- Broadband Internet costs reduced through regulatory reforms

Improving the Business Climate

- Business registration and regulation procedures simplified

- Restrictions on land acquisition by foreigners eased

- New insolvency legislation

- New labor market legislation

Widening the Circle of Opportunity through Participation, Social Inclusion and Sustainability

- The National Empowerment Foundation for training redundant and re-allocated established

- Education reform launched

- Eradicating Absolute Poverty Plan launched

Source: World Bank

\section{RECENT DEVELOPMENTS}

\section{Output growth has slowed sharply in the wake of the global financial crisis, but} is expected to remain positive at about 2 percent in 2009. Growth slowed from 6.6 percent in $2008 \mathrm{H} 1$ to 1.5 percent in $2009 \mathrm{H} 1$ as tourism, textiles, and construction contractedthough financial services remain resilient. Contraction of these labor-intensive sectors has increased the unemployment rate by about 1 percentage point, to almost 8 percent in $2009 \mathrm{Q} 2$, with women (mainly in the textiles sector) particularly affected.

\footnotetext{
${ }^{3}$ These steps are very much in line with staff policy advice to EMEs; see Coping with the Crisis: Policy Options for Emerging Market Economies (SPN/09/08).
} 
5. Inflation has subsided to the low single digits (Figure 2). Since reversal of last year's global food and commodity price shock, and the slowdown of the domestic economy and portfolio inflows, inflationary pressures have eased despite monetary loosening. ${ }^{4}$

6. The current account deficit has narrowed because external demand has been more than offset by reduced imports. Export

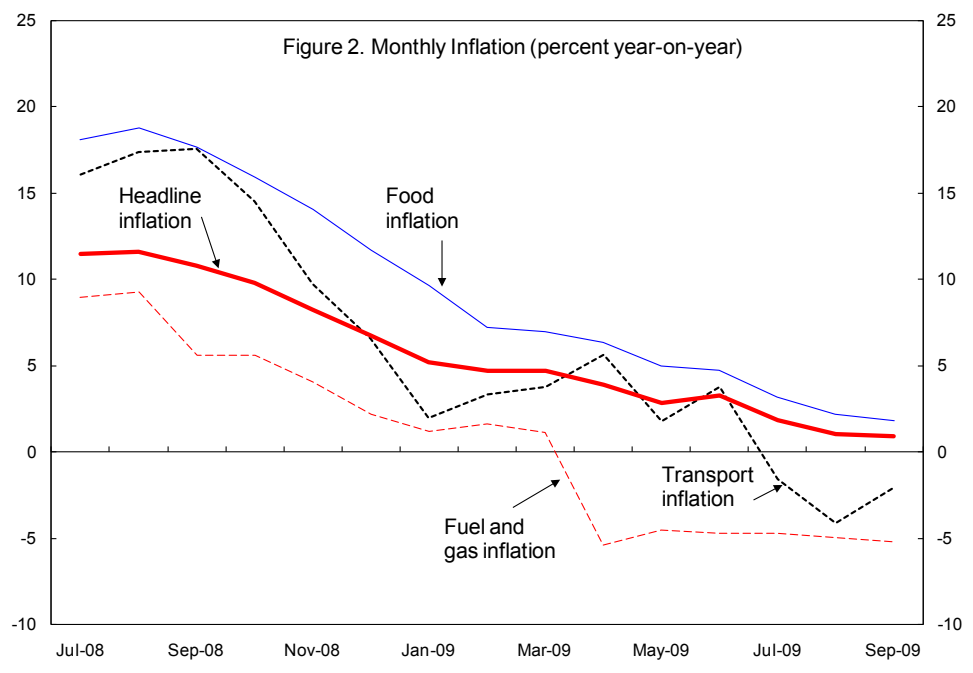
volumes in the first half of 2009 contracted by 3.6 percent compared to the same period in 2008 and are forecast to fall by 11.6 percent in 2009 , and import volumes are expected to fall by 12.8 percent. The current account deficit is therefore expected to narrow by 2.3 percent of GDP. While FDI continues to finance a substantial portion of the current account deficit, it has declined by about $9 \frac{1}{2}$ percent in the first half of 2009 compared to the same period in 2008, and net private capital flows are expected to fall from 9 percent of GDP in 2008 to about 7 percent in 2009 .

\section{The exchange rate has depreciated modestly and reserves coverage remains} comfortable. Within the floating regime, the Bank of Mauritius (BoM) accumulated reserves opportunistically through mid-2008 then allowed them to decline as capital inflows eased late last summer (Figure 3). This trend continued when, in step with international developments, monetary policy was eased in November and again in early December. The BoM has since refrained from interventions, and the floating exchange has depreciated in nominal effective terms by about 4 percent since January 2009 , while remaining relatively stable against the U.S. dollar. ${ }^{5}$

\footnotetext{
${ }^{4}$ Econometric decomposition of the change in inflation during the first two quarters of 2009 suggests that about 25 percent of the change is attributable to external factors (oil prices, global demand); 34 percent to monetary conditions (changes in the repo rate and money demand); and 14 percent due to domestic factors (GDP growth slowdown).

${ }^{5}$ Mauritius' exchange rate regime has been reclassified from a managed float to a free float in the Fund's AREAR.
} 
Figure 3: Exchange Rate Intervention, 2006-2009

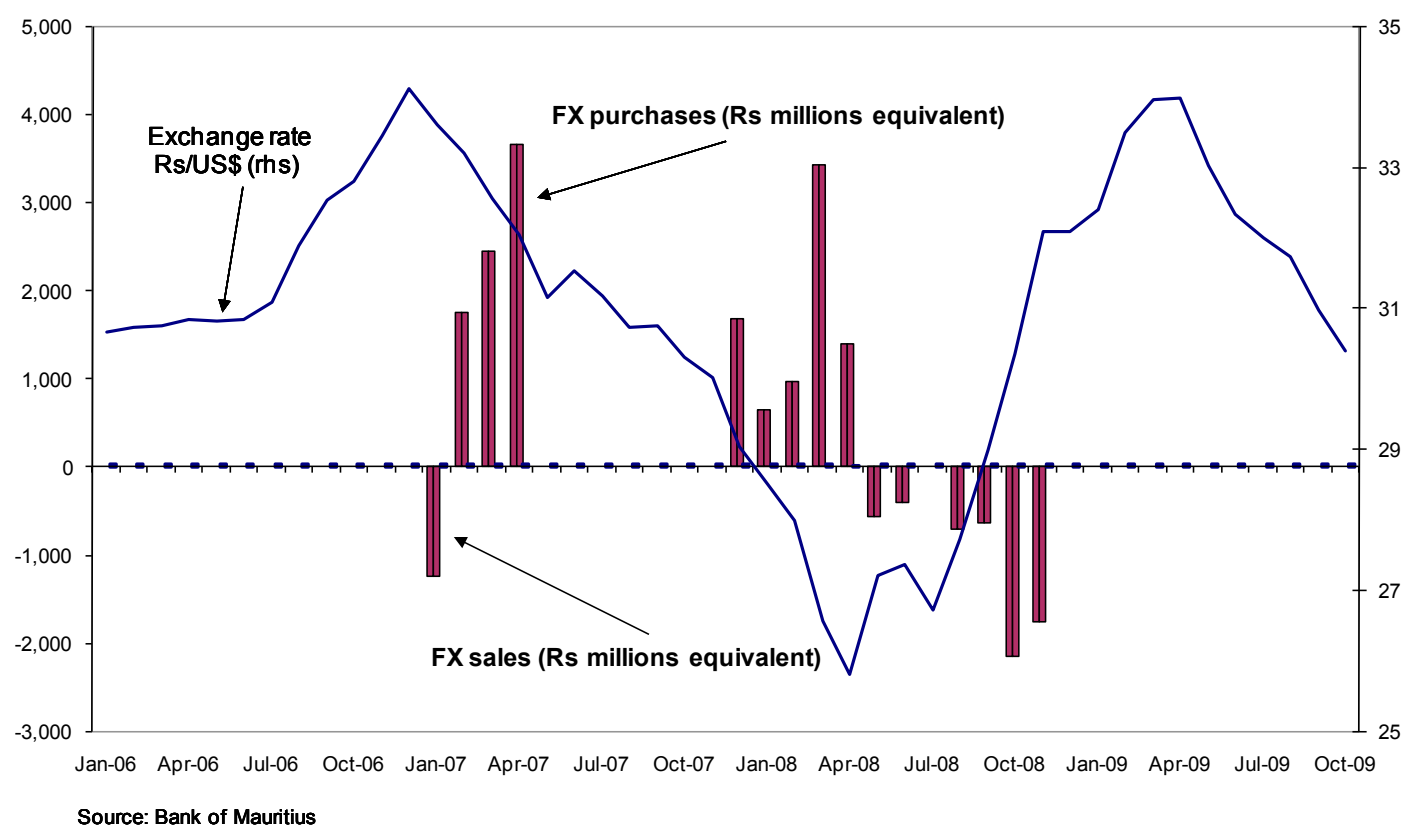

\section{Response to the Global Financial Crisis}

\section{A fiscal stimulus package of about 5 percent of GDP (spread over 2009-10) was a} key element of the policy response. Rough calculations suggest that, inclusive of this package, the fiscal impulse in FY2009/10 will be about 1.5 percent of GDP, commensurate with an estimated output gap of about 1 percent of GDP (Text Table 1). ${ }^{6}$ The targeted and temporary stimulus measures focus on advancing planned infrastructure spending, providing financial relief to the firms hit hardest by the global crisis, and protecting people either through job preservation interventions or direct assistance to the most vulnerable. At the same time, to ensure fiscal discipline and anchor expectations, the government also introduced partially offsetting measures that are expected to bring the primary budget into surplus by the end of 2011. The government has also been using special "rainy day" funds it had prudently put aside in previous financial years (to the tune of 3 percent of GDP), reducing current debt financing needs. In addition, a public debt management act was passed limiting public sector debt to 60 percent of GDP, with a goal of reducing it to 50 percent by 2013.

\footnotetext{
${ }^{6}$ Cross-country evidence suggests fiscal multipliers of about 0.5 for small, open economies; see Fiscal Multipliers, SPN/09/11.
} 
Text Table 1. Growth and Fiscal Performance, Fiscal Years 2006/07-10/11 (in percent)

\begin{tabular}{|c|c|c|c|c|c|}
\hline & $2006 / 07$ & $2007 / 08$ & $\begin{array}{r}2008 / 09 \\
\text { Est. }\end{array}$ & $\begin{array}{r}2009 / 10 \\
\text { Proj. }\end{array}$ & $\begin{array}{r}2010 / 11 \\
\text { Proj. }\end{array}$ \\
\hline Real GDP growth & 3.6 & 7.0 & 2.2 & 2.0 & 4.7 \\
\hline Output gap $1 /$ & 0.0 & 0.5 & 0.8 & -1.2 & -0.5 \\
\hline \multicolumn{6}{|l|}{ Fiscal balance $^{2 l}$} \\
\hline Overall balance & -4.2 & -3.7 & -4.4 & -4.4 & -3.8 \\
\hline Primary balance & -0.2 & 0.5 & -0.6 & -0.8 & -0.4 \\
\hline \multicolumn{6}{|c|}{ Fiscal impulse $(-=\text { stimulus })^{2,3 /}$} \\
\hline Not incl. interest & $\ldots$ & 0.1 & -1.1 & -0.5 & 0.2 \\
\hline Incl. interest payments & $\cdots$ & 0.7 & -0.7 & -0.2 & 0.3 \\
\hline Central Government Debt & 52.8 & 50.2 & 50.0 & 50.2 & 49.7 \\
\hline Of which: Domestic & 46.6 & 45.6 & 43.8 & 41.2 & 39.0 \\
\hline External & 6.1 & 4.6 & 6.1 & 9.0 & 10.7 \\
\hline
\end{tabular}

\section{Monetary policy was}

loosened in tandem. With the economic slowdown and sharp decline in the growth of private sector credit, the BoM reduced its policy rate by 250 basis points to 5.75 percent a year and lowered reserve requirements (Figure 4). To ensure FX liquidity while conserving reserves, the BoM made FX credit available to banks facing rollover problems on FX liabilities, though in the event, only one needed to avail

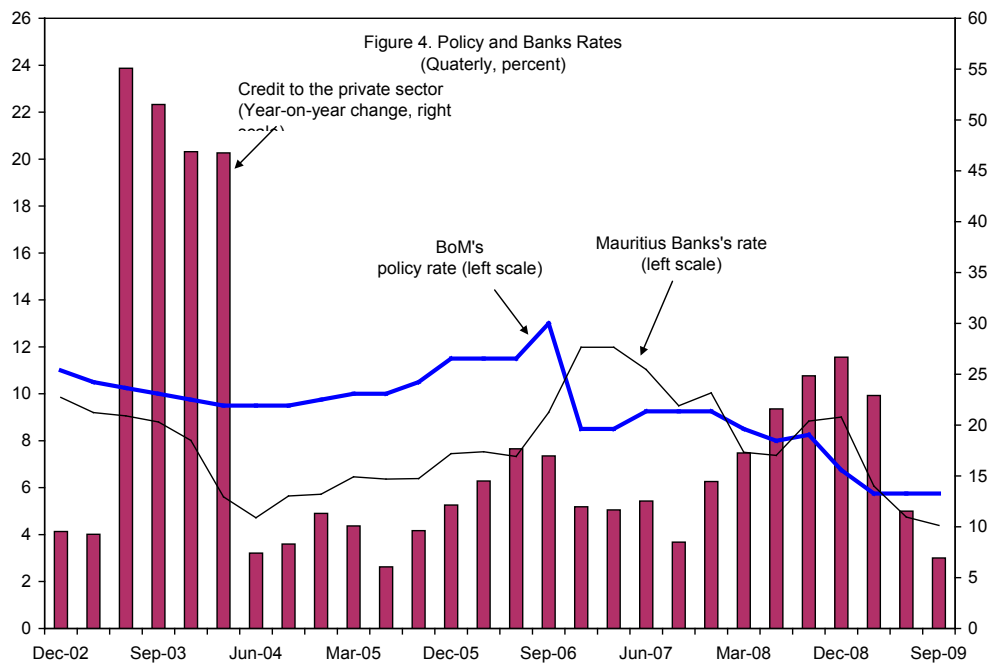
itself of this facility, and in a small amount. 
Chart. Mauritius: Macroeconomic Developments, 2006-09

With falling exports and imports ...

... economic growth has slowed.

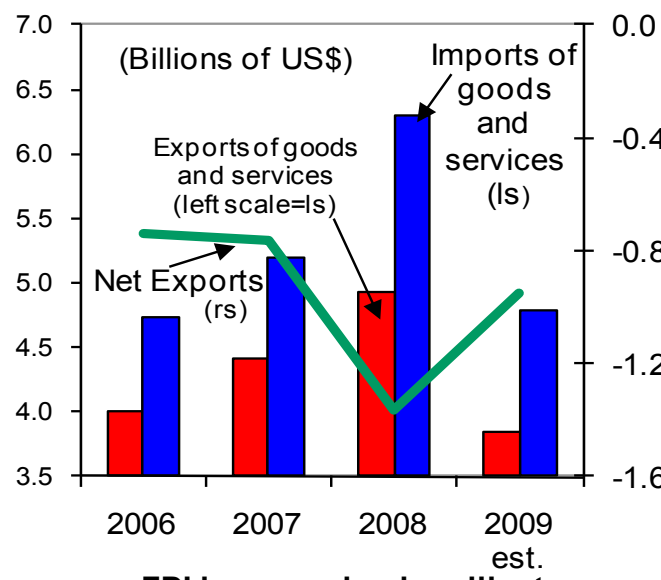

FDI has remained resilient however ...

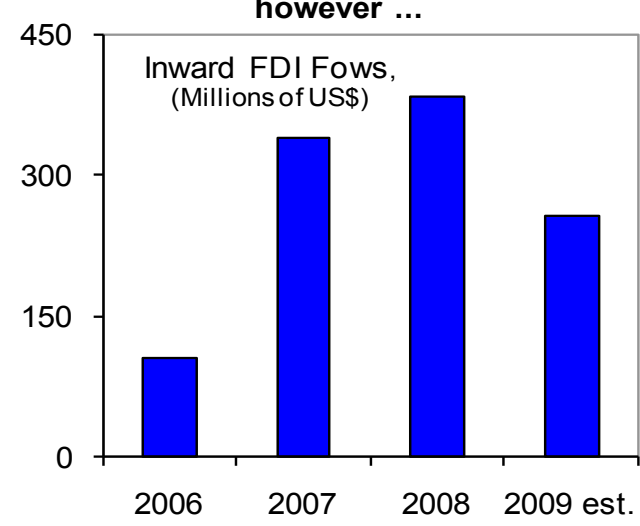

The exchange rate has depreciated moderately ...

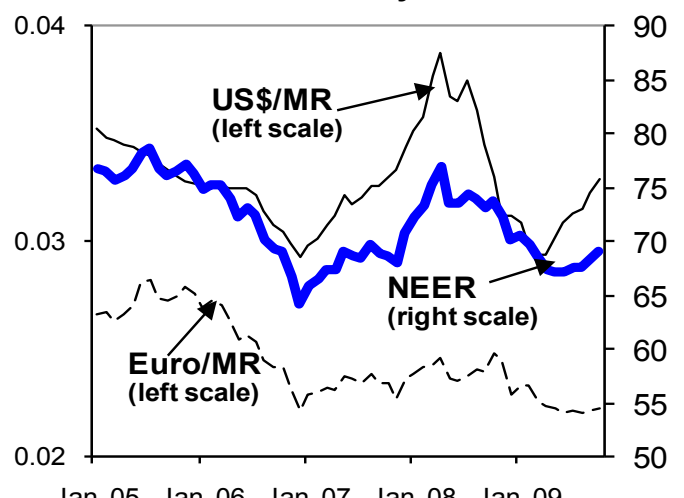

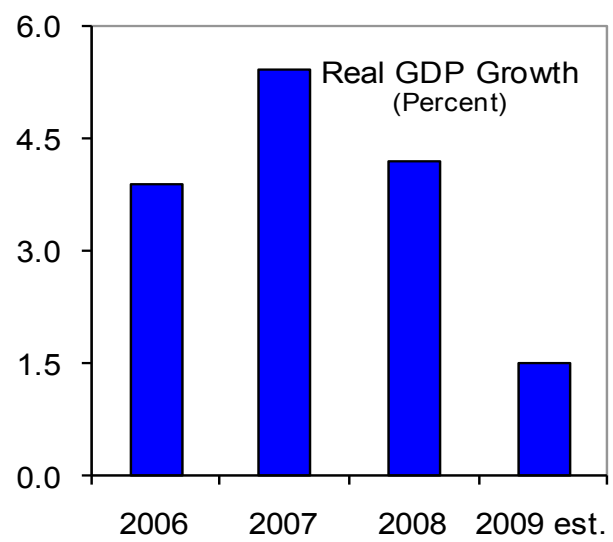

... and reserves have remained comfortable.

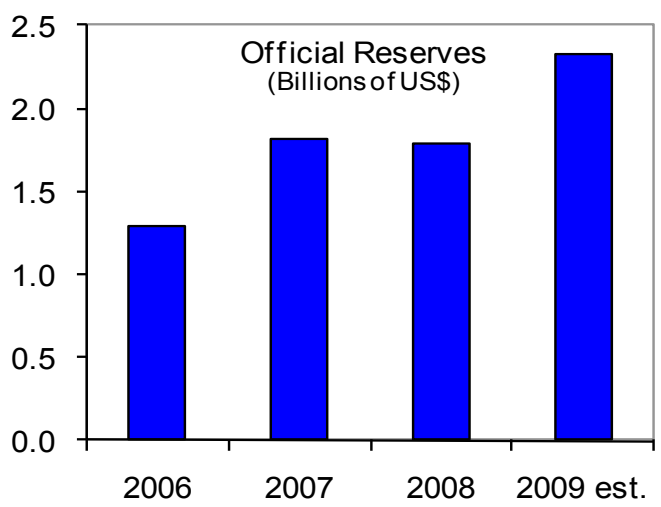

... while inflation is falling rapidly.

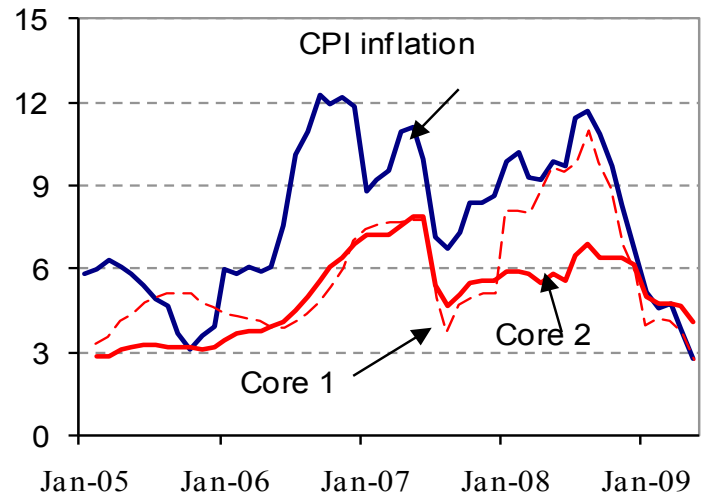

Source: CSO, Bank of Mauritius and IMF Staff estimates. 


\section{To facilitate debt restructuring and avoid inefficient insolvencies, the} government instituted the "Mauritius approach." 7 This provides temporary financial relief to firms facing liquidity problems due to the crisis, conditional on credible restructuring plans, with costs shared by the banks, the government, and the firm's shareholders. Other initiatives to save jobs were a work-cum-training scheme that gave manufacturing and tourism firms an alternative to laying off workers by partially reimbursing wages while workers receive training. A few tax relief and deferrals were also provided to labor-intensive and vulnerable sectors. These timely and temporary measures (most sunset in December 2010) are judged to have had a significant impact in containing unemployment.

\section{OUTLOOK AND RISKS}

\section{The short-term risks and external vulnerabilities of Mauritius appear}

manageable. The exchange rate is estimated to be broadly in line with fundamentals, and external debt appears sustainable ${ }^{8}$ including in the face of the DSA templates' standard shocks. Nevertheless, the current account deficit remains large - although the deficit is likely overestimated (see DSA appendix), and about one-half is financed by FDI (which has remained largely resilient even in the current crisis) - and accordingly poses some inherent financing risk. As of October 2009, official reserves stood at about 6 months of merchandise imports, 22 percent of GDP (twice the size of reported external debt), and about 10 percent of broad money_comfortable coverage for a country with a flexible exchange rate. ${ }^{9}$

\footnotetext{
7 This "Mauritius Approach"- also known as the Mauritian Transitional Support to the Private Sector (MTSP) — is based on burden sharing amongst shareholders, management, creditors, and government. To date, 11 companies have received assistance under the MTSP, to which the government has contributed Rs140 million (36 percent of the total MTSP support for these companies; the rest has been provided by banks and share holder equity) in the form of debentures at 5 percent interest. During the MTSP support, the companies' management may be subject to cuts in salary and benefits and no dividends are paid until the government has redeemed its investment. In regard to the fiscal cost of the program, the authorities estimate that the net present value (NPV) should be zero, and only if some assisted companies fail would the NPV may be negative. All firms assisted so far are doing well, with tight monitoring by the banks and authorities reducing risks to the government budget.

${ }^{8}$ The three CGER-type methodologies yield estimated overvaluations of 1.9 percent for the macroeconomic balance approach (MB), 5.5 for the equilibrium real exchange rate (ERER) approach, and 5.7 for the external sustainability approach (ES) - insignificantly different from zero, given the standard errors of the analysis. For the MB approach, at end-2009 the CA norm is estimated - using CGER coefficients — at 4.7 percent. Using a variety of estimates, the underlying $\mathrm{CA}$ is below the CA norm by $1.0-3.4$ percent of GDP (1.5 percent for the "baseline" underlying CA). Given the estimated elasticity of the current account response to the exchange rate, these estimates suggest a small exchange rate overvaluation of 1.2-4.0 percent (1.9 percent for the "baseline" underlying CA).

${ }^{9}$ Including the general and special SDR allocations (SDR 75.3m, and SDR 5.7m) that the authorities intend to hold as reserves (Table 3 ).
} 


\section{Though exposed to the slowdown, banks remain well-capitalized and seem} resilient to further shocks. They were not holding toxic assets and, especially the large banks that account for more than 70 percent of deposits, remain liquid and well-capitalized despite some increase in nonperforming loans. Because banks hold long FX positions, they would not be adversely affected by a further depreciation of the exchange rate (Box 2).

\section{Over the longer term, Mauritius' growth prospects depend heavily on the global} economy. The medium-term growth forecast remains benign, but there is significant uncertainty. Economic growth is projected to increase to 5 percent per year by 2011 , reflecting a reversal of the growth contraction in the EU, Mauritius' main market for exports and tourism. But further deterioration of the external accounts cannot be ruled out if global demand remains sluggish and capital inflows dry up. And if world demand does begin to pick up too rapidly, there is a risk that a surge in oil prices could more than offset a rebound in demand for Mauritian exports, causing a deterioration of the trade deficit, larger financing requirements, and inflationary pressures.

\section{To support the country's transition from a low-skill sugar and apparel exporter} to an innovative and skill-based services economy, the government needs to continue its ambitious reform agenda. In recent years, the government has revamped regulation, especially with regard to labor, solvency, public debt management, and procurement legislation (see Box 1). But although labor productivity has increased, transferring resources from low- to high-productivity sectors faster is necessary to speed enhancement of overall productivity. The human capital constraint needs to be addressed through a mix of long-run initiatives to improve educational performance and short-term measures to mitigate labor shortages in specific sectors and occupations.

\section{New labor market legislation should facilitate the economic transformation} underway. A new Employment Rights Bill that went into effect in 2009 contains workfare provisions and introduces a "flexi-security" scheme as part of the broader reform of the Industrial Relations Framework, which dated from 1973. The objective of flexi-security is to shift protection from jobs to workers by providing transitional support to those that lose their jobs. ${ }^{10}$ This should lower resistance to structural change and stabilize incomes for households, allowing for greater labor market efficiency and productivity-enhancing labor reallocation.

\footnotetext{
${ }^{10}$ The scheme provides for up to 12 months of transitional assistance to workers who opt to join the program. Workers receive a stipend of 90 percent of the basic wage for the first three months, 60 percent for the second three, and 30 percent for the six after that. In return workers must choose one of three programs offered by the government: (i) job placement; (ii) training and retooling; or (iii) assistance in starting a small business.
} 


\section{Box 2. Financial Sector Stability}

Despite the slowdown, the Mauritian banking system has thus far withstood the impact of the global financial turmoil, for a number of reasons:

- Banks were not holding toxic assets and fund operations mainly through domestic deposits (two-thirds of total liabilities) rather than large-scale interbank foreign borrowing.

- A sizable share (one-third) of total deposits is held in liquid or near-liquid assets.

- Banks have limited exposure to equities, either by way of their own investments or as loan collateral.

- The "Mauritius Approach" has helped avoid costly insolvencies.

- Their positive net foreign exchange FX position contains banks direct exchange rate risk, and limiting FX-denominated lending mainly to export-oriented enterprises contains credit risk.

The capital adequacy, liquidity, and profitability of the system are sound. Moreover, in line with the revised Guideline on Credit Concentration Risk, the ratio of large exposures to capital had declined from 394 at the end of 2008 to 215 by June 2009. Furthermore, bank assets have continued to improve since 2007, although nonperforming loans (NPLs) inched up from 2 percent in 2008 to 2.6 percent at the end of June 2009.

Stress tests show that banks would be generally resilient to a range of adverse shocks but are vulnerable to credit quality. On sensitivity to sector-specific credit shocks, a credit shock to sugar and textiles (with an immediate loss of 20 percent each) leads to a deterioration of the Capital Asset Ratio (CAR) from 16.2 percent to 12.3 percent and the NPLs (to total gross loans) from 2.3 percent to 5.8 percent. As in the 2007 Financial Sector Assessment Program (FSAP), the impact of a 50 percent loss on each bank's third largest exposure was simulated; this leads to a deterioration of CAR from 16.3 percent to 14.7 percent and of NPLs from 2.3 percent to 6.2 percent.

Much progress has been made since the 2007 FSAP update, among them work on the recommendations of the 2007 Basel Core Principles (BCP) assessment, which has already triggered significant reinforcement of banking supervision. For instance, the position of head of the Supervision Division (SD), vacant for the past nine years, has been filled, and the SD has been reorganized to improve its efficiency (it now includes the following divisions: Off-site, On-site and Regulation, and Policy and Licensing). Remaining recommendations of the 2007 FSAP and the 2007 BCP assessment, which are mostly on completion or testing phases, are expected by early 2010; more specifically: (i) a model for risk based supervision has been developed and is being applied on a pilot basis to some banks; (ii) a draft Guideline on BOM intervention is in place; (iii) the final revision of Guideline on liquidity has been issued; (iv) the Guideline on Corporate Governance is being issued; (v) Draft Guideline on country risk has been issued. In addition, substantial progress has been made on the revision of Guidelines on Related Party Transactions and credit concentration and the revision of the guideline on Operational Risk. However, further steps are needed on the completion of the Supervision Manual. 


\section{Policy Discussions}

Discussions centered on the fiscal stance and ensuring sustainability of the public finances; monetary policy, and the monetary and exchange rate policy regime; maintaining the momentum of structural reforms; and improving the coverage of external statistics.

\section{A. Fiscal Policy and Public Debt Sustainability}

16. While agreeing with the accommodative fiscal stance, the mission recommended that some stimulus measures be held contingently in reserve and deployed only if the recovery seems to be faltering - given the uncertain outlook and the challenge of resuming fiscal consolidation without jeopardizing the recovery. Over short term, the government intends to continue its expansionary fiscal policy through the next full fiscal year (JanuaryDecember 2010; Box 3). The authorities agreed, however, that if the recovery is stronger than expected, the need for further stimulus would be correspondingly lower. Indeed, with some early positive signs of recovery, the 2010 deficit is expected to be $4 \frac{1}{2}$ percent of GDP rather than of the originally slated 5 percent. ${ }^{11}$ The authorities explained that several of the stimulus measures (especially support to enterprises and work-cum-training schemes) are in the nature of automatic stabilizers. Moreover, a substantial part of the stimulus package consists of bringing forward public infrastructure investment projects; these can be delayed if the economy seems to be overheating and, in any case, the full program is unlikely to be implemented. The deficit is expected to fall to below 4 percent in 2011 and about 3 percent of GDP in 2012.

\section{The mission welcomed the new public debt law, which should strengthen fiscal} discipline and help ensure medium-term sustainability. ${ }^{12}$ Although immediate financing risks appear limited, reducing public debt will create fiscal space against contingencies ${ }^{13}$ and the eventual costs of an aging population. The mission and the authorities agreed, however, that the debt law as currently formulated may overly constrain the phasing of external financing that the government may obtain and also infrastructure investment undertaken by

\footnotetext{
${ }^{11}$ The borrowing requirement will be limited to 4 percent of GDP including through the sale of Mauritius Telecom shares. On taxes, the government will not increase the VAT and will maintain various tax suspensions in the tourism, construction, and real estate sectors until the end of 2010.

${ }^{12}$ Although Mauritius's public debt is high relative to most emerging market countries (close to 60 percent of GDP compared to an average of 50 percent of GDP for non-fuel exporting EMEs), its vulnerability is limited in part because it is nearly all held domestically by the National Pension Fund and commercial banks. Moreover, appetite for treasury bills remains strong; indeed, one concern of banks is that the government will reduce the domestic financing of its budget. Nonetheless, reducing public debt is important, for which grant support from development partners (including, e.g., continued support from the EC V-FLEX) would be particularly useful.

${ }^{13}$ Sensitivity analysis suggests that fiscal risk factors (e.g., lower revenues) are in the order of 0.5 to 0.6 percent of GDP.
} 
public enterprises, which is critically needed to enhance productivity. Specifically, the law makes no provision for netting uncommitted and freely usable government deposits in the banking system. In addition, nonguaranteed debt of public enterprises that are run on a commercial basis and are not likely to rely on the government budget could be excluded from public debt for the purposes of applying the debt limit. The guaranteed debt of such enterprises could also be discounted, though this is more complicated because it requires an explicit assessment of the likelihood that the guarantee could be called. The authorities further agreed that any modification of the debt law should be done in line with best practices, and not to undermine its critical value in maintaining fiscal discipline and achieving the necessary medium-term consolidation. ${ }^{14}$

18. The mission welcomed the government's efforts to secure external financing, while underscoring that this financing should not widen the deficit, and that there are limits to the substitutability between domestic and external financing. In the uncertain external environment the government has prudently secured significant external financing of about 7 percent of GDP from such sources as the African Development Bank and the World Bank. The authorities recognize that the macroeconomic impact (either a significant increase in base money or a sharp appreciation of the exchange rate) limits the substitutability between domestic and external financing of the budget. ${ }^{15}$ They intend to adopt a pragmatic combination of using external financing to the extent it corresponds to capital imports for public investment, limiting the substitution of domestic borrowing to what the market can absorb, and treating part of the funds as precautionary - in effect, trying to reproduce a contingent credit line (which might have better served their purposes). The authorities are also considering creating a mini-sovereign wealth fund to park funds externally until they might be needed.

${ }^{14}$ See http://www.imf.org/external/np/pp/eng/2009/022509a.pdf (February 2009), Section IV. C.

${ }^{15}$ While the BoM could issue securities to mop up the increase in liquidity, this would be equivalent to domestic financing of the consolidated public sector in the first place — and would include a carry cost on the interest differential. 
Box 3. Mauritius: Fiscal Stimulus Measures for 2010

In the first half of 2009, the authorities began to implement the targeted and temporary stimulus package announced in December 2008. The package accounts for about 5 percent of GDP, of which 3 to 3.5 percent of GDP will be carried out through dedicated funds that were set up at the end of the 2007/08 fiscal year as a contingency to deal with the crisis and were stocked up further in FY2008/09. The Minister of Finance and Economic Empowerment announced in his budget speech on November 18, 2009, that the following measures will be continued until December 2010:

- $\quad$ Continue with direct support to SMEs and large enterprises facing temporary difficulties due to the crisis, so as to protect jobs and enterprises.

- $\quad$ Continue with the work-cum-training program for retrenched workers and the unemployed.

- Maintain the government's commitment to upgrade public infrastructure in education, health, the environment, and sports and to frontload public infrastructure projects to boost construction and create jobs.

- $\quad$ Accelerate private sector investment and improve competitiveness by modernizing machinery and equipment and upgrading skills.

- $\quad$ Continue various tax suspensions to the tourism, construction and real estate sectors to stimulate growth and protect jobs.

- On supporting development of Rodrigues island, (i) maintain additional infrastructure development, (ii) suspend the travel tax to Rodrigues, and (iii) maintain the incentive package for increasing tourism to Rodrigues.

- $\quad$ Sustain a fiscal and monetary policy mix that is supportive of investment, growth, and job creation.

- $\quad$ Step up efforts to protect to the population and strengthen the Eradication of Absolute Poverty Program.

\section{B. Monetary Policy and Framework}

19. With inflationary pressures subdued and the economic outlook still uncertain, the monetary policy stance appears appropriate. At its last two meetings of the Monetary Policy Committee (MPC), against some initial positive signs from the textile and tourism sectors, the MPC decided to leave the key Repo rate unchanged at 5.75 percent per year. The mission considered that, in the current environment, with banks flush with liquidity, it is unlikely that a further reduction in interest rates would significantly spur private lending and activity; but the mission also stressed that the MPC needs to be vigilant against any inflationary pressures. A more "data-driven" approach is therefore appropriate, with the MPC holding the repo rate at its current level pending clearer indications of the state of the economy. 
20. The monetary and exchange rate framework, which may be described as hybrid inflation targeting, seems well-suited to the needs of the Mauritian economy. As a small and highly open economy, the scope for monetary policy to be truly independent of external factors is necessarily limited. In practice, policy interest rate decisions appear to place significant weight on the interest rate differential relative to major currencies (e.g., the US federal funds rate) while reacting to domestic inflation when it is above the tolerance level; FX intervention is limited to smoothing operations, and no intervention has been undertaken since November 2008 (Box 4). This allows the Mauritian monetary and exchange rate regime to combine the flexibility of a floating exchange rate with some of the discipline of a less flexible regime. The authorities agreed with this characterization of their monetary and exchange rate regime and noted that they do not envisage moving soon to a pure IT framework. The mission provided some background on common and best practices for the functioning of MPCs and central bank governance structures.

\section{Box 4: Monetary Policy Reaction Function}

The BoM's real policy interest rate reaction function can be described by: $R_{t}=\beta_{0}+0.03$ ygap $+1.1 * * * D\left(\pi^{e}-\bar{\pi}\right)+0.4 * U_{S F e d}$; where $R$ is the real policy (repo) rate, USFed is the US federal funds rate, $D$ is a dummy variable equal to unity when expected inflation exceeds the threshold level, and the threshold (tolerance) level of inflation is estimated using maximum likelihood methods to be 4.7 percent a year. From the uncovered interest rate parity condition, a high coefficient on the Fed funds rate approximately sets the expected change of the exchange rate to zero (as in a pegged exchange rate regime), but unexpected shocks can be absorbed by exchange rate movements (as in a floating regime). Moreover, the high coefficient on expected inflation (when it exceeds the tolerance level) implies that the policy reaction function obeys the Taylor principle.

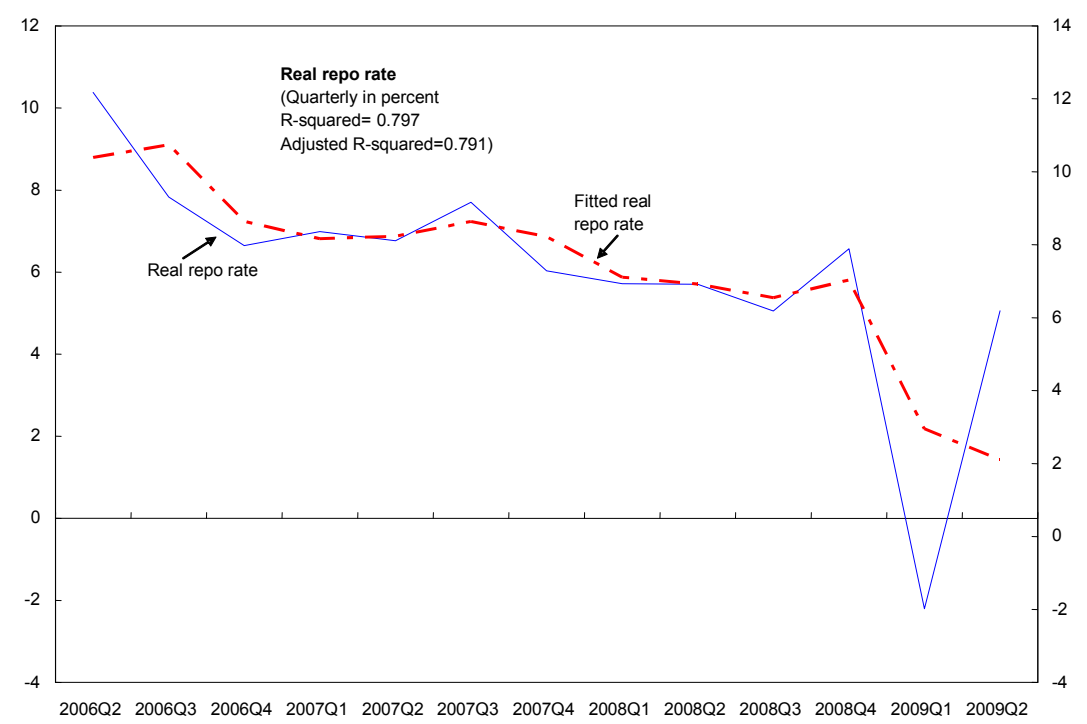

21. The currently low inflation rate may provide an opportunity for Mauritius to adopt a more ambitious tolerance level for inflation. The MPC has been operating with an implicit target (more precisely, tolerance level) for inflation of about 5 percent. Since inflation is now considerably lower, a more ambitious tolerance level (perhaps 3 percent) 
could be considered, with a view to anchoring inflationary expectations at this lower level. ${ }^{16}$ The authorities agreed that this may be an opportune time to anchor low inflationary expectations but also noted the need for further high-frequency indicators as well as econometric modeling to better understand inflation dynamics. They stated that they very much appreciate Fund technical assistance (TA), and the work of the mission, on incorporating available high-frequency data and developing econometric models, and requested that this assistance continue.

\section{Financial Sector, Structural Reforms, and Data Coverage}

\section{The mission welcomed the move towards greater risk-based financial sector supervision and encouraged the speedy implementation of the remaining} recommendations of the 2007 FSAP. The authorities have made significant progress in implementing the 2007 FSAP recommendations, including periodic compliance-based analysis and steps to move toward more risk-based supervision; they agreed that remaining aspects (risk-based supervision, supervision manual, guide on BoM intervention, and off-site work) warrant speedy implementation. The government has requested Fund TA to help design a deposit insurance scheme, as mandated by the BoM 2004 Act and the Banking Act. This would give small, resident retail depositors more explicit assurance while clarifying that the government would not be responsible for large, offshore/non-resident deposits.

\section{The mission welcomed efforts to improve service delivery and efficiency in the} public sector, particularly with regard to the social protection system. To achieve a coherent approach in social policy, different agencies under the aegis of the Ministry of Finance and Economic Empowerment (MOFEE) were integrated into a single organization, the National Empowerment Foundation (NEF), set up in July 2008. ${ }^{17}$ The range of interventions includes training, placement, support for small and medium enterprises, direct financial assistance to most vulnerable groups, and housing. Despite the consolidation, social assistance in Mauritius needs further rationalization to target those that cannot escape poverty and to empower people to exploit new labor market opportunities. This is crucial for assuring that the 4.4 percent of GDP (2008/09 budget) spent on social assistance is used efficiently. Other initiatives to improve service delivery and efficiency in the public sector (such as PMS and parastatal reforms) are underway, including drawing on Fund and Bank TA.

\footnotetext{
${ }^{16}$ Such a move is also facilitated by the change from centralized wage determination to collective bargaining at the national level via the National Pay Council supplemented by flexibility in implementing recommendations at the firm level. The NPC formula of half inflation plus productivity to guide wage setting should favor a low inflation environment.

${ }^{17}$ The NEF provides an overall coordinating framework for the Empowerment Program, the Trust Fund for the Social Integration of Vulnerable Groups, the Eradication of Absolute Poverty Program, the Decentralized Cooperation Program, the Program for Rodrigues and the Corporate Social Responsibility Program.
} 
24. The mission emphasized the need to resolve discrepancies in the balance of payments (BOP) and to improve external statistics to meet SDDS requirements. A joint committee comprising the BoM, Financial Services Commission (FSC) and MoFEE has been established to conduct a BOP survey of resident GBCs managed by 12 major management companies (MCs). ${ }^{18}$ The objective of the survey is to enhance coverage of the BOP statistics and the international investment position (IIP) - a critical requirement for subscription to the SDDS. The mission also urged the BoM to reissue the Foreign Assets and Liabilities Survey (FALS), which was first launched as an exploratory survey in November 2007 to collect data from resident companies on their cross-border financial flows and stocks. The authorities stated that they recognized the importance of improving the coverage of external statistics, including understanding the large positive errors and omissions in the BOP statistics, and are committed to doing so as soon as practicable; they expect to be ready to apply for subscription to the SDDS by mid-2010.

\section{Staff Appraisal}

\section{The authorities' prompt and comprehensive policy response has been} instrumental in cushioning the economy from the fallout of the global financial crisis. Staff considers that the magnitude of the fiscal stimulus and extent of monetary easing to have been appropriate to the external shock from the global financial crisis. Together with more micro measures to restructure debts of illiquid enterprises and save private sector jobs, the policy response has been instrumental in cushioning the economy from the crisis impact.

\section{The challenge now is how to begin withdrawing the stimulus and working} toward further fiscal consolidation without jeopardizing the recovery. Despite shocks and the current crisis, public debt over the period 2006-2010 will be lower than in the previous five years, and stochastic simulations suggest a strong likelihood of further declines over the following five years. Nevertheless, public debt remains high and fiscal consolidation will be important to reduce the inherent risks. In addition, fiscal consolidation will also help reduce the large external current account deficit, which carries financing risks. Given uncertain conditions, the authorities have rightly decided on some contingent stimulus measures that will be deployed only if the recovery falters. Careful management of the mix of external and domestic financing of public debt is also required. In the longer term, the challenge will be to sustain reform efforts, enhance productivity, and improve the costeffectiveness of public sector service delivery.

27. Mauritius remains vulnerable to global developments-but the private sector is dynamic, economic fundamentals are strong, institutions are robust, and the authorities have

\footnotetext{
${ }^{18}$ The first-round survey of GBCs is on track; the FSC sent the survey to the 12 MCs on September 25 with a submission deadline of March 31, 2010.
} 
not only implemented far-reaching reforms in an environment of continued macroeconomic stability, they have also established a track record of strong policy responses to unexpected shocks. Some further reduction in public debt levels, monetary policy refinements, financial sector and structural reforms, and data improvements will both improve the economy's resilience and better position Mauritius to compete with other EMEs, including as a financial center.

28. Staff recommends that the next Article IV consultation be held on the standard 12month cycle. 
Table 1. Mauritius: Selected Economic and Financial Indicators, 2005-2013

\begin{tabular}{|c|c|c|c|c|c|c|c|c|c|}
\hline & 2005 & 2006 & 2007 & 2008 & 2009 & 2010 & 2011 & 2012 & 2013 \\
\hline & & & & & \multicolumn{5}{|c|}{ Projections } \\
\hline & \multicolumn{9}{|c|}{ (Annual percent change, unless otherwise indicated) } \\
\hline \multicolumn{10}{|l|}{ National income, prices and employment } \\
\hline \multicolumn{10}{|l|}{ Real GDP } \\
\hline Market prices & 1.5 & 3.9 & 5.4 & 4.2 & 1.5 & 4.1 & 4.7 & 4.9 & 5.0 \\
\hline Factor costs & 2.4 & 5.2 & 5.5 & 5.2 & 2.7 & 4.1 & 4.7 & 5.1 & 5.2 \\
\hline Real GDP per capita & 0.7 & 3.2 & 4.7 & 3.3 & 0.7 & 3.3 & 4.0 & 4.2 & 4.3 \\
\hline GDP deflator & 4.0 & 7.2 & 8.3 & 8.1 & 4.0 & 5.0 & 5.0 & 5.0 & 5.0 \\
\hline Domestic demand at current prices ${ }^{2}$ & 13.0 & 17.8 & 14.2 & 12.2 & 7.8 & 9.5 & 8.4 & 7.2 & 9.3 \\
\hline Consumer prices (period average) & 4.9 & 9.0 & 8.8 & 9.7 & 3.0 & 4.3 & 4.2 & 4.2 & 4.2 \\
\hline Consumer prices (end of period) & 3.9 & 11.8 & 8.7 & 6.8 & 4.0 & 3.0 & 4.9 & 4.5 & 4.1 \\
\hline Unemployment rate (percent) & 9.6 & 9.1 & 8.5 & 7.2 & $\ldots$ & $\ldots$ & $\ldots$ & $\ldots$ & $\ldots$ \\
\hline \multicolumn{10}{|l|}{ External sector } \\
\hline Exports of goods, f.o.b. & 7.3 & 8.9 & -4.7 & 7.3 & -23.5 & 7.2 & 3.1 & 3.6 & 2.9 \\
\hline Of which : tourism receipts & 2.2 & 15.6 & 29.0 & 11.5 & -24.4 & 5.1 & 5.0 & 7.1 & 9.1 \\
\hline Imports of goods, f.o.b. & 14.0 & 16.4 & 6.0 & 20.6 & -24.5 & 9.5 & 4.1 & 4.5 & 6.5 \\
\hline Nominal effective exchange rate (annual averages) & -7.4 & -7.0 & -4.4 & 7.8 & -4.0 & $\ldots$ & $\ldots$ & $\ldots$ & $\ldots$ \\
\hline Real effective exchange rate (annual averages) & -3.8 & -0.7 & 1.2 & 13.0 & 4.1 & $\ldots$ & $\ldots$ & $\ldots$ & $\ldots$ \\
\hline Terms of trade & -8.4 & -5.8 & -1.0 & -1.1 & 1.6 & $\ldots$ & $\ldots$ & $\ldots$ & $\ldots$ \\
\hline & \multicolumn{9}{|c|}{ (Annual change in percent of beginning of period M2, unless otherwise indicated) } \\
\hline \multicolumn{10}{|l|}{ Money and credit ${ }^{2}$} \\
\hline Net foreign assets & 6.9 & 48.8 & 13.1 & 8.1 & 3.7 & 13.7 & 6.9 & 7.0 & 7.1 \\
\hline Domestic credit & 14.7 & 10.2 & 11.7 & 22.5 & 8.9 & 14.6 & 12.9 & 13.6 & 13.3 \\
\hline Net claims on government & 1.6 & 0.5 & -0.3 & 0.6 & -1.3 & 4.9 & 0.3 & -0.4 & 0.2 \\
\hline Credit to private sector ${ }^{3}$ & 13.0 & 9.7 & 12.0 & 21.9 & 10.3 & 9.6 & 12.6 & 14.0 & 13.2 \\
\hline Broad money (end of period, annual percentage change) & 11.1 & 9.5 & 15.3 & 14.7 & 12.5 & 13.3 & 9.3 & 9.6 & 9.6 \\
\hline Income velocity of broad money & 0.9 & 0.9 & 0.9 & 0.9 & 1.0 & 1.0 & 1.0 & 1.0 & 1.0 \\
\hline Interest rate (weighted average TBs, primary auctions) & 6.4 & 7.5 & 11.0 & 7.4 & 4.8 & $\ldots$ & $\ldots$ & $\ldots$ & $\ldots$ \\
\hline & \multicolumn{9}{|c|}{ (Percent of GDP) } \\
\hline \multicolumn{10}{|l|}{ Central government budget } \\
\hline Overall balance (including grants) & -5.3 & -4.6 & -4.0 & -3.4 & -4.5 & -4.5 & -3.9 & -3.0 & -2.2 \\
\hline Primary Balance (including grants) & -1.8 & -0.2 & 0.5 & 0.7 & -1.1 & -1.1 & -0.7 & 0.2 & 0.7 \\
\hline Revenues and grants & 20.1 & 19.3 & 22.0 & 22.5 & 21.1 & 21.9 & 20.9 & 20.3 & 20.6 \\
\hline Expenditure and net lending & 25.8 & 23.6 & 25.7 & 26.1 & 25.6 & 25.9 & 24.7 & 23.1 & 22.7 \\
\hline Domestic debt of central government & 51.4 & 46.6 & 45.6 & 43.8 & 42.6 & 41.4 & 38.5 & 34.2 & 31.1 \\
\hline External debt of central government & 4.4 & 6.1 & 4.6 & 6.1 & 8.0 & 8.8 & 11.0 & 13.6 & 13.9 \\
\hline \multicolumn{10}{|l|}{ Investment and saving } \\
\hline Gross domestic investment & 21.4 & 24.3 & 25.1 & 24.6 & 26.3 & 26.2 & 24.6 & 24.6 & 24.8 \\
\hline Public & 7.5 & 6.9 & 6.4 & 5.0 & 6.1 & 7.6 & 6.5 & 7.0 & 7.4 \\
\hline Private & 14.0 & 17.3 & 18.7 & 19.6 & 20.2 & 18.5 & 18.1 & 17.6 & 17.4 \\
\hline Gross national savings & 17.4 & 17.1 & 21.2 & 16.7 & 14.2 & 14.3 & 16.8 & 18.8 & 21.5 \\
\hline Public & -1.5 & -1.1 & -0.5 & -1.1 & -1.1 & -0.8 & -0.7 & 0.4 & 1.3 \\
\hline Private & 18.8 & 18.2 & 21.7 & 17.9 & 15.3 & 15.1 & 17.5 & 18.4 & 20.1 \\
\hline \multicolumn{10}{|l|}{ External sector } \\
\hline Balance of goods and services & -6.0 & -11.3 & -10.3 & -14.7 & -11.1 & -11.4 & -11.1 & -10.4 & -10.3 \\
\hline Exports of goods and services, f.o.b. & 59.9 & 61.6 & 58.8 & 52.9 & 45.1 & 45.2 & 44.2 & 43.1 & 41.8 \\
\hline Imports of goods and services, f.o.b. & -65.9 & -72.9 & -69.0 & -67.5 & -56.2 & -56.6 & -55.3 & -53.5 & -52.1 \\
\hline Current account balance & -5.2 & -9.4 & -5.6 & -10.4 & -8.1 & -8.5 & -8.0 & -7.5 & -6.9 \\
\hline Overall balance & -2.6 & -2.2 & 5.9 & 1.7 & 5.4 & 0.0 & 1.5 & 0.6 & 0.9 \\
\hline Total external debt ${ }^{4}$ & 13.9 & 12.7 & 11.4 & 12.0 & 13.8 & 12.2 & 15.9 & 18.0 & 17.3 \\
\hline Net international reserves, BOM (millions of U.S. dollars) & 1,361 & 1,297 & 1,814 & 1,784 & 1,989 & 2,039 & 2,088 & 2,152 & 2,375 \\
\hline Net international reserves, BOM (months of imports of goods, c.i.f.) & 5.2 & 4.3 & 5.6 & 4.6 & 6.6 & 6.6 & 6.5 & 6.4 & 6.7 \\
\hline \multicolumn{10}{|l|}{ Memorandum item: } \\
\hline GDP at current market prices (millions of Mauritian rupees) & 185,349 & 206,328 & 235,519 & 265,196 & 280,264 & 305,219 & 334,500 & 367,400 & 408,760 \\
\hline GDP at current market prices (millions of U.S. dollars) & 6,284 & 6,507 & 7,521 & 9,321 & 8,527 & $\ldots$ & $\ldots$ & $\ldots$ & $\cdots$ \\
\hline Foreign currency long-term debt rating (Moody's) & Baa2 & Baa1 & Baa2 & Baa2 & $\ldots$ & $\ldots$ & $\ldots$ & $\ldots$ & \\
\hline
\end{tabular}

Sources: Bank of Mauritius; Central Statistics Office; Ministry of Finance and Empowerment; Moody's; and IMF staff estimates and projections.

${ }^{1}$ Excluding changes in stocks.

2 Percent of beginning of period M2. End-2009 data refer to June.

${ }^{3}$ Includes credit to parastatals.

${ }^{4}$ Reported debt only, excluding private sector short-term debt. 
Table 2. Mauritius: Summary of Central Government Finances , 2006/07?2011

\begin{tabular}{|c|c|c|c|c|c|c|c|}
\hline & \multirow[t]{2}{*}{$2006 / 07$} & \multirow[t]{2}{*}{$2007 / 08$} & \multicolumn{2}{|c|}{$2008 / 09$} & \multirow{2}{*}{$\begin{array}{r}2009 \text { (Jul.-Dec.) } \\
\text { Prel. }\end{array}$} & 2010 & 2011 \\
\hline & & & Budget & Act. & & \multicolumn{2}{|c|}{ Proj. } \\
\hline & \multicolumn{7}{|c|}{ (Percent of GDP) } \\
\hline Total revenue and grants & 19.3 & 22.0 & 21.9 & 22.9 & 21.1 & 21.9 & 20.9 \\
\hline Total revenue & 19.2 & 21.0 & 20.5 & 21.9 & 18.8 & 20.5 & 19.6 \\
\hline Tax revenue & 17.5 & 19.0 & 18.1 & 19.3 & 17.2 & 17.3 & 17.7 \\
\hline Taxes on net income and profits & 3.5 & 4.2 & 4.1 & 5.6 & 4.7 & 4.5 & 4.6 \\
\hline Of which: Individuals & 1.1 & 1.4 & 1.4 & 1.5 & 1.5 & 1.3 & 1.5 \\
\hline Corporate & 2.4 & 2.5 & 2.4 & 3.8 & 2.8 & 2.9 & 2.8 \\
\hline Taxes on property & 1.3 & 1.6 & 1.0 & 1.5 & 1.0 & 1.1 & 1.4 \\
\hline Taxes on goods and services & 11.5 & 12.1 & 11.1 & 10.8 & 10.3 & 10.1 & 10.4 \\
\hline Of which: VAT & 7.1 & 7.4 & 7.2 & 7.0 & 6.4 & 6.7 & 7.0 \\
\hline Taxes on international trade & 1.0 & 1.1 & 0.5 & 0.6 & 0.5 & 0.5 & 0.5 \\
\hline Other indirect taxes & 0.2 & 0.0 & 1.3 & 0.8 & 0.6 & 1.0 & 0.9 \\
\hline Nontax revenue & 1.7 & 2.0 & 2.4 & 2.6 & 1.7 & 3.3 & 1.9 \\
\hline Grants & 0.2 & 1.0 & 1.4 & 1.0 & 2.3 & 1.3 & 1.3 \\
\hline Total expenditure and net lending & 23.6 & 25.7 & 25.2 & 26.5 & 25.6 & 25.9 & 24.7 \\
\hline Current expenditure & 20.2 & 22.1 & 22.6 & 23.9 & 22.2 & 22.7 & 21.6 \\
\hline Expenditures on goods and services & 7.5 & 6.7 & 8.0 & 7.9 & 8.1 & 8.5 & 7.7 \\
\hline Wages and salaries & 5.6 & 5.0 & 6.1 & 6.0 & 6.0 & 6.2 & 5.7 \\
\hline Other goods and services & 1.9 & 1.7 & 1.9 & 1.9 & 2.1 & 2.3 & 2.0 \\
\hline Interest payments & 4.1 & 4.2 & 3.9 & 3.8 & 3.4 & 3.3 & 3.2 \\
\hline External interest & 0.1 & 0.1 & 0.1 & 0.1 & 0.3 & 0.2 & 0.3 \\
\hline Domestic interest & 3.9 & 4.1 & 3.8 & 3.7 & 3.1 & 3.1 & 2.9 \\
\hline Current transfers and subsidies & 8.6 & 11.1 & 10.1 & 12.2 & 10.7 & 10.2 & 10.2 \\
\hline Other expenditures: contingency & n.a. & n.a. & 0.6 & 0.0 & 0.0 & 0.7 & 0.5 \\
\hline Capital expenditure and net lending & 3.4 & 3.6 & 2.6 & 2.6 & 3.5 & 3.2 & 3.1 \\
\hline Capital expenditure & 3.2 & 3.0 & 2.6 & 2.0 & 3.4 & 3.7 & 3.2 \\
\hline Lending minus repayment & 0.2 & 0.6 & 0.1 & 0.6 & 0.1 & -0.5 & -0.1 \\
\hline Overall balance after grants (including net lending) & -4.2 & -3.7 & -3.3 & -3.6 & -4.5 & -4.0 & -3.8 \\
\hline Overall balance after grants (excluding net lending) & -4.1 & -3.1 & -3.3 & -3.0 & -4.5 & -4.5 & -3.9 \\
\hline Primary balance (including net lending) & -0.2 & 0.5 & 0.6 & 0.8 & -1.1 & -1.1 & -0.7 \\
\hline Financing, net & 4.2 & 3.7 & 3.3 & 3.6 & 4.5 & 4.0 & 3.8 \\
\hline External, net & 0.8 & 0.8 & 1.8 & 1.3 & 3.2 & 1.5 & 2.9 \\
\hline Disbursements & 1.3 & 1.2 & 2.1 & 2.0 & 3.6 & 1.8 & 3.2 \\
\hline Amortization & -0.4 & -0.4 & -0.4 & -0.8 & -0.4 & -0.3 & -0.3 \\
\hline \multirow[t]{2}{*}{ Domestic, net } & 3.4 & 2.9 & 1.5 & 2.3 & 1.4 & 2.0 & 0.9 \\
\hline & \multicolumn{7}{|c|}{ (Millions of Mauritian rupees) } \\
\hline Total revenue and grants & 42,327 & 55,327 & 61,583 & 62,216 & 31,361 & 66,770 & 69,800 \\
\hline Total expenditure and net lending & 51,607 & 64,626 & 70,871 & 74,256 & 38,085 & 78,987 & 82,594 \\
\hline Overall balance after grants & $-9,280$ & $-9,299$ & $-9,288$ & $-12,040$ & $-6,724$ & $-12,217$ & $-12,794$ \\
\hline \multicolumn{8}{|l|}{ Memorandum items: } \\
\hline Government debt (percent of GDP) & 52.8 & 50.2 & 50.0 & 48.4 & 50.7 & 50.3 & 49.6 \\
\hline Public sector debt ${ }^{2,3}$ (percent of GDP) & 62.7 & 60.0 & 59.9 & 56.9 & 59.7 & 58.5 & 57.4 \\
\hline GDP at current market prices (millions of rupees) & 218,822 & 251,502 & 280,729 & 271,503 & 148,500 & 305,219 & 334,500 \\
\hline
\end{tabular}

Sources: Ministry of Finance and Empowerment; Bank of Mauritius; and IMF staff estimates and projections.

1 Fiscal years through 2008/09: July/June.

2 Includes central government, local government, and parastatals.

3 Starting in 2006/07, this includes central and local government and parastatals, after netting out investments of the Consolidated Sinking Fund (which accounts for 3 percent of GDP) in government securities. 
Table 3. Mauritius: Balance of Payments, 2005-2014

\begin{tabular}{|c|c|c|c|c|c|c|c|c|c|c|}
\hline & & & & & & & & Projections & & \\
\hline & 2005 & 2006 & 2007 & 2008 & 2009 & 2010 & 2011 & 2012 & 2013 & 2014 \\
\hline & & & (Million & s of U.S. d & llars, unles & s otherwis & indicated) & & & \\
\hline Current account balance & -324.4 & -611.8 & -423.1 & -971.2 & -694.4 & -791.7 & -792.6 & -803.2 & -799.4 & -873.3 \\
\hline Trade balance & -797.2 & $-1,089.1$ & $-1,403.2$ & $-1,989.2$ & $-1,477.0$ & $-1,659.2$ & $-1,745.1$ & $-1,841.4$ & $-2,035.5$ & $-2,166.7$ \\
\hline Exports of goods, f.o.b. & $2,143.3$ & $2,335.0$ & $2,226.1$ & $2,388.9$ & $1,827.7$ & $1,958.8$ & $2,020.1$ & $2,093.8$ & $2,153.7$ & $2,199.4$ \\
\hline Imports of goods, f.o.b. & $-2,940.5$ & $-3,424.0$ & $-3,629.3$ & $-4,378.0$ & $-3,304.7$ & $-3,618.0$ & $-3,765.3$ & $-3,935.1$ & $-4,189.2$ & $-4,366.1$ \\
\hline Services (net) & 420.0 & 354.2 & 631.9 & 620.5 & 527.7 & 602.0 & 644.6 & 732.0 & 849.2 & $1,018.8$ \\
\hline Of which: tourism & 596.5 & 678.9 & 943.8 & 997.2 & 757.7 & 762.6 & 804.8 & 871.9 & 962.1 & $1,071.3$ \\
\hline Income (net) & -8.1 & 51.5 & 224.3 & 172.2 & 76.6 & 113.5 & 167.4 & 181.7 & 262.4 & 150.2 \\
\hline Current transfers (net) & 60.9 & 71.6 & 124.0 & 225.2 & 178.3 & 152.0 & 140.6 & 124.5 & 124.5 & 124.5 \\
\hline Capital and financial accounts & 306.6 & 182.6 & 503.4 & 903.1 & 761.2 & 792.5 & 939.7 & 867.4 & 908.8 & 902.1 \\
\hline Capital account & -1.8 & -2.6 & -1.6 & -1.4 & -1.5 & -1.8 & -1.8 & -1.8 & -1.8 & -1.8 \\
\hline Financial account & 308.3 & 185.2 & 505.0 & 904.5 & 762.7 & 794.3 & 941.5 & 869.2 & 910.6 & 903.9 \\
\hline Direct investment (net) & -6.0 & 95.2 & 281.0 & 330.8 & 222.1 & 368.2 & 379.5 & 435.5 & 531.0 & 521.1 \\
\hline Abroad & -47.5 & -10.1 & -58.0 & -52.2 & -33.5 & -36.8 & -40.5 & -44.5 & -49.0 & -53.9 \\
\hline In Mauritius & 41.6 & 105.3 & 339.1 & 382.9 & 255.6 & 405.0 & 420.0 & 480.0 & 580.0 & 575.0 \\
\hline Portfolio investment (net) & -16.3 & -27.7 & 63.5 & -171.1 & -49.2 & 100.0 & 100.0 & 100.0 & 100.0 & 100.0 \\
\hline Other investment (net) & 164.9 & 117.7 & 160.5 & 744.9 & 589.8 & 326.1 & 461.9 & 333.7 & 279.6 & 282.8 \\
\hline Of which: SDR allocation ${ }^{2}$ & $\ldots$ & $\ldots$ & $\ldots$ & $\ldots$ & 126.5 & $\ldots$ & $\ldots$ & $\ldots$ & $\ldots$ & $\ldots$ \\
\hline Of which: government (net) & 14.8 & -82.8 & 50.6 & 55.3 & 156.8 & 310.4 & 237.5 & 257.8 & 195.7 & 261.3 \\
\hline Errors and omissions ${ }^{3}$ & 17.9 & 285.0 & 362.9 & 230.6 & 389.6 & 0.0 & 0.0 & 0.0 & 0.0 & 0.0 \\
\hline Overall balance & -165.7 & -144.2 & 443.3 & 162.5 & 456.4 & 0.8 & 147.1 & 64.1 & 109.4 & 28.8 \\
\hline Change in official reserves $(-=$ increase $)$ & 165.7 & 144.2 & -443.3 & -162.5 & -456.4 & -0.8 & -147.1 & -64.1 & -109.4 & -28.8 \\
\hline Memorandum items: & & & (Per & cent of GD & $P$, unless 0 & therwise in & dicated) & & & \\
\hline Balance of goods and services & -6.0 & -11.3 & -10.3 & -14.7 & -11.1 & -11.4 & -11.1 & -10.4 & -10.3 & -9.2 \\
\hline Exports of goods and services, f.o.b. & 59.9 & 61.6 & 58.8 & 52.9 & 45.1 & 45.2 & 44.2 & 43.1 & 41.8 & 40.9 \\
\hline Imports of goods and services, f.o.b. & -65.9 & -72.9 & -69.0 & -67.5 & -56.2 & -56.6 & -55.3 & -53.5 & -52.1 & -50.1 \\
\hline Foreign direct investment & 0.7 & 1.6 & 4.5 & 4.1 & 3.0 & 4.4 & 4.2 & 4.5 & 5.0 & 4.6 \\
\hline Current account balance & -5.2 & -9.4 & -5.6 & -10.4 & -8.1 & -8.5 & -8.0 & -7.5 & -6.9 & -7.0 \\
\hline Overall balance & -2.6 & -2.2 & 5.9 & 1.7 & 5.4 & 0.0 & 1.5 & 0.6 & 0.9 & 0.2 \\
\hline Errors and omissions ${ }^{3}$ & 0.3 & 4.4 & 4.8 & 2.5 & 4.6 & 0.0 & 0.0 & 0.0 & 0.0 & 0.0 \\
\hline Net international reserves, BOM, (mill. of U.S. dollars) & $1,361.2$ & $1,297.4$ & $1,814.4$ & $1,784.3$ & $1,988.8$ & $2,039.4$ & $2,088.0$ & $2,152.2$ & $2,374.6$ & $2,571.7$ \\
\hline In months of imports of goods, c.i.f. & 5.2 & 4.3 & 5.6 & 4.6 & 6.6 & 6.6 & 6.5 & 6.4 & 6.7 & 6.9 \\
\hline GDP (millions of U.S. dollars) & 6,284 & 6,507 & 7,521 & 9,321 & 8,527 & 9,285 & 9,894 & 10,659 & 11,566 & 12,456 \\
\hline Total external debt & 13.9 & 12.7 & 11.4 & 12.0 & 13.8 & 12.2 & 15.9 & 18.0 & 17.3 & 17.3 \\
\hline Total debt service ratio (percent of exports of goods and services & 6.1 & 6.1 & 3.6 & 3.4 & 4.5 & 4.0 & 3.9 & 3.4 & 3.1 & 2.8 \\
\hline Mauritian rupees per U.S. dollar (period average) & 29.5 & 31.7 & 31.3 & 28.5 & 32.9 & $\ldots$ & $\ldots$ & $\ldots$ & $\ldots$ & $\ldots$ \\
\hline Mauritian rupees per U.S. dollar (end of period) & 30.7 & 34.3 & 28.2 & 31.8 & 32.1 & $\ldots$ & $\ldots$ & $\ldots$ & $\ldots$ & $\ldots$ \\
\hline
\end{tabular}

Sources: Bank of Mauritius; Ministry of Finance; Mauritius Sugar Syndicate; and IMF staff estimates and projections.

${ }^{1}$ Fiscal year (July-June), analytical presentation.

${ }^{2}$ Mauritius received an SDR allocation of SDR 75.3 million on August 28 and SDR 5.7 million on September 9 (total of US\$126.5 million).

${ }^{3}$ The 2006/07 budget announced the integration of EPZ and non-EPZ sectors. 
Table 4. Mauritius: Depository Corporations Survey, December 2006?June 2009

\begin{tabular}{|c|c|c|c|c|c|c|c|c|c|c|c|}
\hline & \multirow{2}{*}{$\begin{array}{l}2006 \\
\text { Dec. }\end{array}$} & \multicolumn{4}{|c|}{2007} & \multicolumn{4}{|c|}{2008} & \multicolumn{2}{|c|}{2009} \\
\hline & & Mar. & Jun. & Sept. & Dec. & Mar. & Jun. & Sept. & Dec. & Mar. & Jun. \\
\hline & \multicolumn{11}{|c|}{ (Millions of rupees) } \\
\hline Net foreign assets & 239,095 & 230,828 & 243,085 & 266,807 & 266,304 & 264,886 & 295,283 & 280,423 & 285,787 & 286,395 & 304,631 \\
\hline Net domestic assets & $-31,574$ & $-19,614$ & $-27,677$ & $-43,704$ & $-26,985$ & $-22,972$ & $-43,108$ & $-20,422$ & $-11,307$ & $-7,234$ & $-20,853$ \\
\hline Domestic credit & 218,007 & 217,456 & 226,550 & 227,730 & 242,190 & 253,444 & 277,278 & 281,049 & 296,098 & 300,885 & 299,757 \\
\hline Claims on government (net) & 46,181 & 43,038 & 42,242 & 42,882 & 45,524 & 48,910 & 53,175 & 50,276 & 46,967 & 49,488 & 49,791 \\
\hline Monetary authorities & 6,116 & 1,332 & $-1,417$ & -179 & -270 & -278 & $-4,362$ & $-7,083$ & $-3,797$ & $-6,398$ & $-10,175$ \\
\hline Commercial banks & 40,065 & 41,706 & 43,660 & 43,061 & 45,795 & 49,188 & 57,537 & 57,358 & 50,764 & 55,886 & 59,965 \\
\hline Claims on private sector ${ }^{1}$ & 171,826 & 174,418 & 184,308 & 184,848 & 196,666 & 204,535 & 224,103 & 230,774 & 249,131 & 251,398 & 249,966 \\
\hline Other financial liabilities ${ }^{2}$ & $-167,431$ & $-158,223$ & $-172,353$ & $-191,350$ & $-188,761$ & $-194,836$ & $-229,974$ & $-212,487$ & $-207,939$ & $-207,021$ & $-216,148$ \\
\hline Other items (net) & $-82,151$ & $-78,847$ & $-81,875$ & $-80,083$ & $-80,415$ & $-81,580$ & $-90,411$ & $-88,985$ & $-99,465$ & $-101,099$ & $-104,462$ \\
\hline Broad money (M2) & 207,521 & 211,214 & 215,408 & 223,103 & 239,318 & 241,914 & 252,175 & 260,001 & 274,481 & 279,161 & 283,778 \\
\hline Money (M1) & 53,148 & 53,188 & 54,599 & 58,341 & 64,429 & 61,670 & 66,576 & 66,534 & 75,987 & 77,478 & 81,149 \\
\hline Quasi-money & 154,373 & 158,025 & 160,809 & 164,762 & 174,889 & 180,244 & 185,599 & 193,467 & 198,494 & 201,683 & 202,629 \\
\hline Reserve Money & 12,208 & 13,267 & 16,206 & 17,563 & 17,424 & 17,616 & 19,421 & 29,294 & 28,047 & 30,144 & 29,969 \\
\hline \multicolumn{12}{|l|}{ Memorandum Items: } \\
\hline & \multicolumn{11}{|c|}{ (Annual change, millions of rupees) } \\
\hline Net foreign assets & 92,493 & 66,678 & 73,060 & 68,401 & 27,208 & 34,058 & 52,198 & 13,616 & 19,484 & 21,510 & 9,347 \\
\hline Domestic credit & 19,299 & 15,799 & 14,032 & 9,897 & 24,183 & 35,989 & 50,728 & 53,319 & 53,908 & 47,441 & 22,479 \\
\hline Claims on government & 931 & $-2,421$ & $-6,505$ & $-4,577$ & -657 & 5,872 & 10,933 & 7,394 & 1,443 & 578 & $-3,384$ \\
\hline Claims on private sector ${ }^{1}$ & 18,369 & 18,221 & 20,537 & 14,475 & 24,840 & 30,117 & 39,795 & 45,926 & 52,465 & 46,863 & 25,863 \\
\hline Broad money (M2) & 18,081 & 16,088 & 16,996 & 21,020 & 31,797 & 30,700 & 36,768 & 36,898 & 35,162 & 37,248 & 31,602 \\
\hline Money (M1) & 5,464 & 6,633 & 6,532 & 9,060 & 11,281 & 8,481 & 11,977 & 8,193 & 11,558 & 15,808 & 14,573 \\
\hline Quasi money & 12,617 & 9,455 & 10,464 & 11,961 & 20,516 & 22,219 & 24,791 & 28,705 & 23,605 & 21,439 & 17,030 \\
\hline & \multicolumn{11}{|c|}{ (Annual percent change) } \\
\hline Domestic credit & 9.7 & 7.8 & 6.6 & 4.5 & 11.1 & 16.5 & 22.4 & 23.4 & 22.3 & 18.7 & 8.1 \\
\hline Claims on government & 2.1 & -5.3 & -13.3 & -9.6 & -1.4 & 13.6 & 25.9 & 17.2 & 3.2 & 1.2 & -6.4 \\
\hline Claims on private sector ${ }^{1}$ & 12.0 & 11.7 & 12.5 & 8.5 & 14.5 & 17.3 & 21.6 & 24.8 & 26.7 & 22.9 & 11.5 \\
\hline Broad money (M2) & 9.5 & 8.2 & 8.6 & 10.4 & 15.3 & 14.5 & 17.1 & 16.5 & 14.7 & 15.4 & 12.5 \\
\hline Money (M1) & 11.5 & 14.2 & 13.6 & 18.4 & 21.2 & 15.9 & 21.9 & 14.0 & 17.9 & 25.6 & 21.9 \\
\hline Quasi-money & 8.9 & 6.4 & 7.0 & 7.8 & 13.3 & 14.1 & 15.4 & 17.4 & 13.5 & 11.9 & 9.2 \\
\hline \multirow[t]{2}{*}{ Reserve Money } & -9.5 & 0.8 & 19.3 & 29.0 & 42.7 & 32.8 & 19.8 & 66.8 & 61.0 & 71.1 & 54.3 \\
\hline & \multicolumn{11}{|c|}{ (Percentage change of beginning of year of broad money) } \\
\hline Net foreign assets & 48.8 & 32.1 & 35.2 & 33.0 & 13.1 & 14.2 & 21.8 & 5.7 & 8.1 & 7.8 & 3.7 \\
\hline Domestic credit & 10.2 & 7.6 & 6.8 & 4.8 & 11.7 & 15.0 & 21.2 & 22.3 & 22.5 & 17.3 & 8.9 \\
\hline Claims on government (net) & 0.5 & -1.2 & -3.1 & -2.2 & -0.3 & 2.5 & 4.6 & 3.1 & 0.6 & 0.2 & -1.3 \\
\hline Claims on private sector ${ }^{1}$ & 9.7 & 8.8 & 9.9 & 7.0 & 12.0 & 12.6 & 16.6 & 19.2 & 21.9 & 17.1 & 10.3 \\
\hline
\end{tabular}

Sources: Bank of Mauritius; and IMF staff estimates.

${ }^{1}$ Including claims on public enterprises.

${ }^{2}$ The major component of other financial liabilities consists of restricted deposits, which largely include deposits of the offshore nonfinancial corporations (so-called Global License 
Table 5. Mauritius: Financial Soundness Indicators for the Banking Sector, 2002-2009 ${ }^{1}$

(End of period, in percent, unless otherwise indicated)

\begin{tabular}{|c|c|c|c|c|c|c|c|c|}
\hline & 2002 & 2003 & 2004 & 2005 & 2006 & 2007 & 2008 & $\begin{array}{l}2009 \\
\text { June }\end{array}$ \\
\hline \multicolumn{9}{|l|}{ Capital adequacy } \\
\hline Regulatory capital to risk-weighted assets ${ }^{2}$ & 12.3 & 14.2 & 15.0 & 15.4 & 15.8 & 13.3 & 15.3 & 16.3 \\
\hline Regulatory Tier I capital to risk-weighted asse & 13.0 & 13.7 & 13.7 & 13.5 & 13.7 & 11.5 & 13.7 & 14.1 \\
\hline Total (regulatory) capital to total assets & 7.2 & 8.0 & 7.8 & 7.8 & 7.3 & 6.0 & 7.3 & 7.9 \\
\hline \multicolumn{9}{|l|}{ Asset composition and quality } \\
\hline \multicolumn{9}{|c|}{ Share of loans (exposures) per risk-weight (RW) category } \\
\hline$R W=0 \%$ & 9.5 & 5.2 & 6.4 & 16.6 & 12.8 & 9.1 & 9.0 & 20.7 \\
\hline$R W=10 \%$ & & & & & & 0.3 & 0.2 & $\ldots$ \\
\hline$R W=20 \%$ & 0.4 & 4.8 & 6.7 & 0.2 & 1.3 & 3.9 & 3.3 & 23.6 \\
\hline$R W=50 \%$ & 7.0 & 7.9 & 9.6 & 6.5 & 6.0 & 5.7 & 5.2 & 8.2 \\
\hline$R W=100 \%$ & 83.2 & 82.1 & 77.3 & 76.7 & 79.8 & 81.1 & 82.3 & 39.8 \\
\hline Total exposures/total assets & 51.6 & 47.8 & 45.9 & 53.6 & 40.1 & 44.8 & 54.9 & 40.1 \\
\hline \multicolumn{9}{|l|}{ Sectoral distribution of loans to total loans } \\
\hline Agriculture & 9.7 & 9.1 & 7.5 & 5.7 & 5.7 & 6.0 & 6.1 & 6.1 \\
\hline of which: sugar & 8.6 & 8.0 & 6.4 & 5.6 & 5.0 & 4.8 & 5.0 & 4.9 \\
\hline Manufacturing & 16.1 & 14.8 & 13.6 & 12.0 & 11.2 & 10.2 & 9.4 & 9.0 \\
\hline of which: EPZ & 9.4 & 7.5 & 6.1 & 5.4 & 4.8 & 4.7 & 4.0 & 3.7 \\
\hline Traders & 14.1 & 14.9 & 14.5 & 13.9 & 14.9 & 13.5 & 11.7 & 11.6 \\
\hline Personal and professional & 9.2 & 9.8 & 10.0 & 9.4 & 9.5 & 9.7 & 8.6 & 8.6 \\
\hline Construction & 13.9 & 14.2 & 16.2 & 15.2 & 15.4 & 16.4 & 18.7 & 19.0 \\
\hline of which: housing & 10.5 & 9.0 & 10.8 & 10.7 & 12.0 & 10.9 & 12.4 & 12.2 \\
\hline Tourism/hotels & 15.0 & 15.9 & 15.4 & 13.2 & 13.2 & 13.6 & 15.4 & 15.0 \\
\hline Other & 21.3 & 21.2 & 22.8 & 30.7 & 30.1 & 30.6 & 45.6 & 45.8 \\
\hline Foreign currency loans to total loans & 10.3 & 10.9 & 12.2 & 51.5 & 50.7 & 56.3 & 65.5 & 62.3 \\
\hline NPLs to gross loans - excluding accrued/unpe & 8.3 & 9.6 & 8.1 & 4.0 & 3.0 & 2.5 & 2.0 & 2.6 \\
\hline NPLs net of provisions to capital & 34.0 & 28.1 & 22.4 & 11.4 & 7.0 & 9.1 & 8.2 & 10.7 \\
\hline Large exposure to capital ${ }^{3}$ & 263.7 & 220.9 & 200.0 & 250.3 & 380.0 & 493.2 & 394.2 & 215.7 \\
\hline \multicolumn{9}{|l|}{ Earnings and Profitability } \\
\hline ROA (Pre-tax net income/average assets) & 2.0 & 2.1 & 2.1 & 1.9 & 1.7 & 1.9 & 1.7 & 1.6 \\
\hline ROE (Pre-tax net income/average equity) & 18.1 & 19.2 & 19.2 & 21.1 & 22.4 & 26.4 & 24.3 & 21.1 \\
\hline Interest margin to gross income & 32.6 & 32.1 & 34.7 & 36.3 & 31.2 & 27.6 & 29.7 & 68.6 \\
\hline Noninterest expenses to gross income & 23.1 & 23.9 & 27.7 & 20.1 & 16.4 & 15 & 17.2 & 38.8 \\
\hline Expenses/revenues & 10.5 & 10.6 & 10.2 & 8.1 & 7.7 & 6.8 & 8.5 & $\ldots$ \\
\hline Earnings/employee - in 000 of rupees & 1,819 & 2,212 & 2,433 & 2,904 & 2,817 & 3,402 & $\ldots$ & $\cdots$ \\
\hline \multicolumn{9}{|l|}{ Liquidity } \\
\hline Liquid assets to total assets ${ }^{4}$ & 32.7 & 36.6 & 37.9 & 44.1 & 52.8 & 47.7 & 27.7 & 28.7 \\
\hline Liquid assets to total short-term liabilities ${ }^{4}$ & 65.3 & 71.0 & 71.7 & 88.6 & 118.8 & 104.2 & 31.9 & 34.4 \\
\hline Funding volatility ratio & 16.4 & 13.9 & 14.0 & -20.1 & -51.6 & -33.7 & -9.3 & ... \\
\hline Demand deposits/total liabilities & 10.3 & 10.3 & 10.7 & 15.9 & 15.4 & 18.4 & 19.4 & 23.9 \\
\hline FX deposits to total deposits & 11.7 & 11.0 & 13.8 & 57.3 & 68.0 & 67.6 & 66.0 & 64.1 \\
\hline \multicolumn{9}{|l|}{ Sensitivity to market risk } \\
\hline Net open positions in FX to capital ${ }^{4}$ & 7.5 & 20.8 & 1.9 & 4.2 & 6.4 & 3.2 & 3.8 & 6.7 \\
\hline
\end{tabular}

Source: Mauritian authorities.

${ }^{1}$ Banking sector refers to former Category 1 banks up to December 2004 and to all banks thereafter.

${ }^{2}$ Total of Tier I and Tier 2 less investments in subsidiaries and associates.

${ }^{3}$ Prior to June 2006, data refer to Category 1 banks only.

${ }^{4}$ Ratio has been revised according to manual as from 2008 
Table 6. Mauritius: Indicators of Financial and External Vulnerability, 2005-2012 ${ }^{1 /}$

\begin{tabular}{|c|c|c|c|c|c|c|c|c|c|}
\hline & & 2005 & 2006 & 2007 & 2008 & 2009 & 2010 & 2011 & 2012 \\
\hline & & & & & \multicolumn{5}{|c|}{ Projections } \\
\hline \multicolumn{10}{|l|}{ Financial Indicators } \\
\hline Total central government debt (percent of GDP) & \# & 55.8 & 52.8 & 50.2 & 50.0 & 50.6 & 50.2 & 49.5 & 47.8 \\
\hline Total public sector debt (percent of GDP) & & 68.8 & 62.7 & 60.0 & 59.9 & 59.7 & 58.5 & 57.4 & 55.9 \\
\hline Broad money (percent change; 12-month basis) & & 4.2 & 9.5 & 15.3 & 14.7 & 12.5 & $\ldots$ & $\ldots$ & $\ldots$ \\
\hline Private sector credit (percent change; 12 -month basis) & & 5.7 & 12.0 & 14.5 & 26.7 & 11.5 & $\ldots$ & $\ldots$ & $\ldots$ \\
\hline Treasury Bill rate (weighted average of primary auctions) & & 6.4 & 7.5 & 11.0 & 7.4 & 4.8 & $\ldots$ & $\ldots$ & $\ldots$ \\
\hline \multicolumn{10}{|l|}{ External indicators } \\
\hline Exports (percent change, in U.S. dollar terms) & & 7.3 & 8.9 & -4.7 & 7.3 & -23.5 & 7.2 & 3.1 & 3.6 \\
\hline Imports (percent change, in U.S. dollar terms) 2/ & & 14.0 & 16.4 & 6.0 & 20.6 & -24.5 & 9.5 & 4.1 & 4.5 \\
\hline Terms of trade (percent change) & & -8.4 & -5.8 & -1.0 & -1.1 & 1.6 & $\ldots$ & $\ldots$ & \\
\hline Current account balance (percent of GDP) & & -5.2 & -9.4 & -5.6 & -10.4 & -8.1 & -8.5 & -8.0 & -7.5 \\
\hline Capital and financial account balance (percent of GDP) & & 4.9 & 5.0 & 0.8 & 7.9 & 3.6 & 7.9 & 8.9 & 7.6 \\
\hline \multicolumn{10}{|l|}{ Net international reserves of the Bank of Mauritius } \\
\hline Millions of U.S. dollars 3 / & & 1,361 & 1,297 & 1,814 & 1,784 & 1,989 & 2,045 & 2,068 & 2,137 \\
\hline Months of imports, c.i.f. 2/ & & 5.2 & 4.3 & 5.6 & 4.6 & 6.6 & 6.6 & 6.5 & 6.4 \\
\hline \multicolumn{10}{|l|}{ Net international reserves of the banking system } \\
\hline Millions of U.S. dollars & & 3,660 & 4,576 & 6,619 & 7,967 & 7,657 & 8,040 & 8,442 & 8,864 \\
\hline Months of imports, c.i.f. 2/ & & 18.1 & 22.9 & 29.3 & 23.2 & 31.7 & 30.6 & 29.8 & 28.4 \\
\hline Total long and medium-term external debt (percent of GDP) & & 13.9 & 12.7 & 11.4 & 12.0 & 13.8 & 12.2 & 15.9 & 18.0 \\
\hline Percent of exports of goods and services & & 23.2 & 20.7 & 19.4 & 22.8 & 30.6 & 26.9 & 36.0 & 41.8 \\
\hline \multicolumn{10}{|l|}{ Total external debt service } \\
\hline Percent of exports of goods and nonfactor services & & 6.1 & 6.1 & 3.6 & 3.4 & 4.5 & 4.0 & 3.9 & 3.4 \\
\hline Of which: interest payments & & 0.8 & 0.7 & 0.7 & 0.6 & 0.7 & 0.9 & 1.0 & 1.4 \\
\hline Of which: principal repayments & & 5.3 & 5.4 & 2.8 & 2.8 & 3.8 & 3.1 & 2.9 & 2.1 \\
\hline Exchange rate (Mauritian rupees per U.S. dollar; period average) & & 29.5 & 31.7 & 31.3 & 28.5 & 32.9 & 32.9 & 33.8 & 34.5 \\
\hline \multicolumn{10}{|l|}{ Financial market indicators } \\
\hline Mauritius stock exchange index (SEMDEX; July $1989=100) 4 /$ & & 1194 & 1820 & 1179 & 1412 & $\ldots$ & $\ldots$ & $\ldots$ & $\ldots$ \\
\hline Change in percent & & 62.1 & 52.4 & -35.2 & 19.7 & $\ldots$ & $\ldots$ & $\ldots$ & $\ldots$ \\
\hline Foreign currency long-term debt rating by Moody's 4/ & & Baa2 & Baa1 & Baa2 & Baa2 & $\ldots$ & $\ldots$ & $\ldots$ & $\ldots$ \\
\hline
\end{tabular}

Sources: Mauritian authorities; and IMF staff estimates and projections.

1/ Fiscal year (July-June).

2/ Excluding the acquisition of aircraft and ships.

$3 /$ The reserves of the Bank of Mauritius are not pledged as collateral for short-term liabilities, nor are they sold forward.

4/ Bonds rated "Baa2" by Moody's are considered as medium-grade obligations. 


\section{APPEndix. DebT Sustainability AnAlysis}

\section{Assumptions}

The macroeconomic projection assumes that the government will resume fiscal consolidation as part of its post-crisis strategy and that growth will be higher, driven by rising foreign and domestic investment, and supported by ongoing structural reforms to improve competitiveness. Assuming no major negative shocks, GDP growth is expected to trend at 5 percent. The fiscal deficit will continue to decline as fiscal consolidation is resumed and financial discipline on public enterprises is better enforced. The primary balance, which was positive in 2007/08 and 2008/09, is projected to be negative in 2009 and 2010 but turn positive again in the medium term. Public investment is projected to rise to support higher growth.

\section{Public Debt}

In Mauritius the public finances are fundamentally sound and public debt is sustainable over the medium-term; the new Public Debt Management Act provides additional safeguards. With the launching of a wide-ranging reform strategy in 2005, the government has successfully implemented program-based budgeting within a medium-term expenditure framework, and the new debt law stipulates a reduction in public debt to 50 percent of GDP by 2013. Since fiscal consolidation began in 2005, public debt has been reduced from a peak of over 80 percent of GDP in 2003 to 54 percent in 2008. The forward-looking debt sustainability analysis (DSA) suggests that public debt will remain sustainable over the medium term (Table 1). It incorporates the fiscal stimulus measures, which are projected to push the deficit up to 4 percent of GDP in calendar 2009 and 4.5 percent in 2010 from about 3 percent in 2007 and 2008. Based on this scenario, public debt peaks at slightly below 60 percent of GDP in 2009 before falling to 52 percent in 2014, the end of the projection period. This adjustment is consistent with commitments under the Public Debt Management Act, which limits public sector debt to 60 percent of GDP and targets a medium-term reduction to 50 percent under "normal" circumstances. The results of standardized tests do not alter the general assessment because no scenario raises the debt ratio above levels observed as recently as 2004. Indeed, the only scenario in which debt exceeds the authorities' own limit of 60 percent of GDP is when the primary deficit remains at its 2009 level over the full projection horizon (2009-14; Table 1); however, the authorities do not intend to maintain the deficit at its 2009 level, which was relatively large due to the economic downturn and stimulus. The mediumterm scenario is also quite resilient to macroeconomic shocks: if growth were about 1 percent lower than projected, the debt-to-GDP ratio would increase to 56 percent of GDP (Figure 1).

Stochastic simulation of public debt dynamics in Mauritius suggests that, on the baseline projection for the primary balance (which incorporates the stimulus package), there is a strong 
likelihood that the public debt ratio will at least stabilize, and may fall marginally, over the next five years (Box 1).

\section{External Debt}

External debt is sustainable. Excluding short-term private sector liabilities, it stood at 13.4 percent of GDP at the end of 2009, down from 19.6 percent in 2002. Official estimates of short-term private sector debt are only about 1 percent of GDP - almost surely it is underreported. A preliminary survey suggests that total short-term external liabilities of the nonfinancial private sector are unlikely to be higher than 10 percent of GDP; an updated survey is planned for the end of 2009. Gross bank external liabilities were about 100 percent of GDP at the end of July 2009 and are not included in external debt as bank foreign assets are almost twice as large, ${ }^{1}$ and as in many international financial centers, it would be misleading to include gross bank liabilities in the external debt measure. ${ }^{2}$ Including banks' position on a net basis in external debt shows that the net external debt position for the economy as a whole is generally balanced (Box 2). Projections suggest that external debt will rise over the next few years before stabilizing at about 19 percent of GDP, and debt dynamics remain stable in the face of DSA template shocks. ${ }^{3}$

\footnotetext{
${ }^{1}$ Bank investments of the GBC float - that is, money from foreign investors meant to be transferred to third countries but held for a short period by GBCs in bank deposits - are included. Excluding these GBC counterpart investments would still result in a positive bank net foreign asset position.

${ }^{2}$ See Debt Sustainability Analysis for Market Access Countries Guidance Note (July 5, 2005), available at http://wwwintranet.imf.org/departments/SPR/Debt/Pages/DSAMarketAccess.aspx.

${ }^{3}$ Historically, there are large positive errors and omissions in the balance of payments. These likely reflect, inter alia, management fees earned by GBCs (which are not captured in the BOP statistics, which treat GBCs as nonresidents), as well as, possibly, capital inflows. For the purposes of DSA projections, the authorities' estimate of likely management fees is included in the service receipts of the current account. Nevertheless, the projections likely overestimate the increase in external debt, as the unaccounted errors and omissions are unlikely to be all debt-creating.
} 


\section{Box 1. Stochastic Debt Sustainability Analysis}

Monte Carlo simulations of public debt dynamics around the baseline projection (using shocks based on the estimated variance-covariance matrix of the primary balance, real GDP growth, and the real interest rate) yield a declining debt ratio after 2010, with the mean of the distribution at about 50 percent of GDP by 2014 (marginally lower than the baseline projection of 52 percent with the 90 percent confidence interval of [41, 61]; see Figure). Endogenizing the primary balance to allow it to react to the level of public debt yields a statistically significant regression coefficient of 0.1 , implying that for each 10 percent of GDP that public debt increases, the primary balance in Mauritius has, historically, improved by 1 percent of GDP. This compares favorably to advanced economies (where the average coefficient is 0.02) and to other EMEs (where the average coefficient is 0.04$).{ }^{1}$ Incorporating this primary balance reaction function yields a somewhat lower mean debt ratio of 48 percent of GDP by 2014 with the 90 percent confidence interval of [41, 56], which suggests that the primary balance in the baseline projection is not implausible given Mauritius' historical performance and its ongoing fiscal reform efforts.

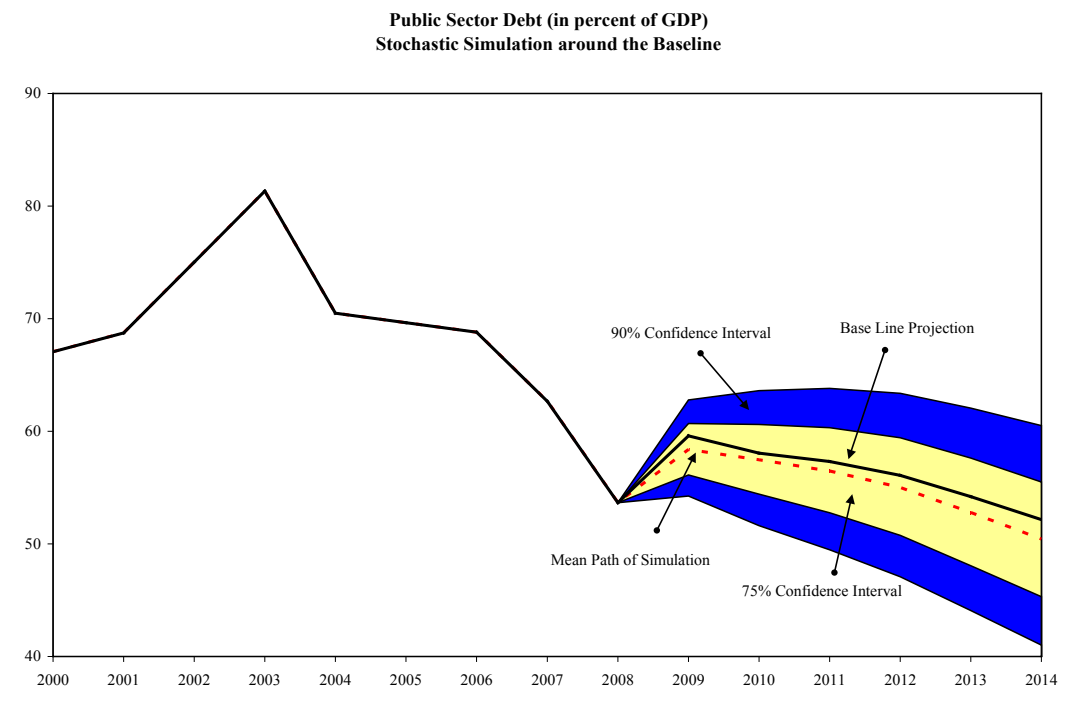

Public Sector Debt (in percent of GDP) Stochastic Simulation with Historical Primary Balance Reaction

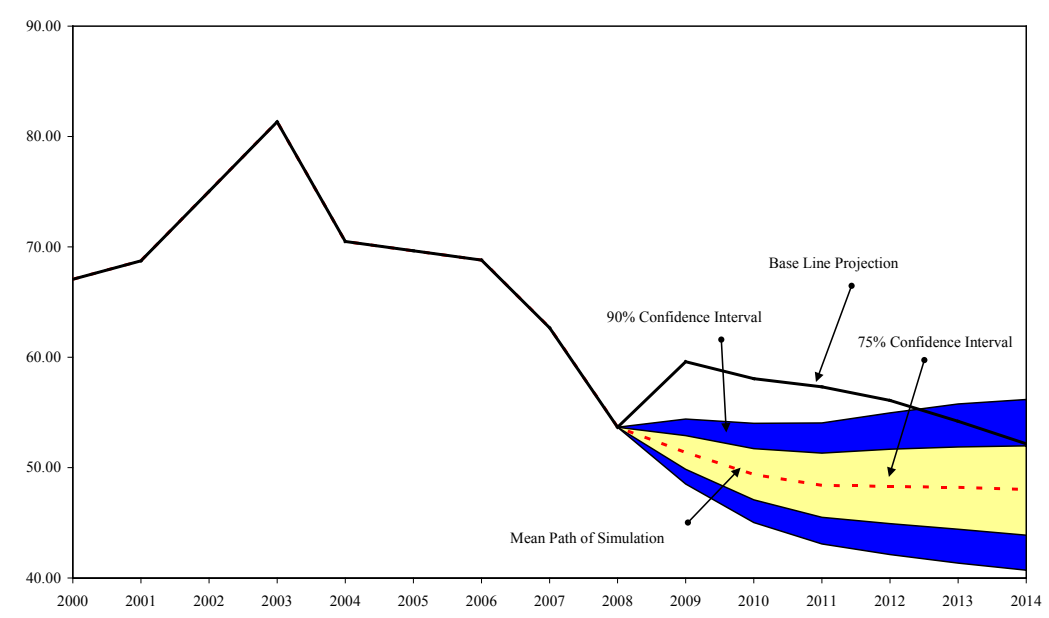

${ }^{1}$ See Mendoza and Ostry (2008), "International Evidence on Fiscal Solvency: Is Fiscal Policy "Responsible”?, Journal of Monetary Economics, vol. 55, pp. 1081-93. 


\section{Box 2. Aggregate Balance Sheet of Mauritius Banks}

As noted in the text, the DSA excludes bank foreign assets and foreign liabilities (following DSA policies for financial centers), but does such an "outsized" banking system nevertheless pose risks?

Structure of the banking system. The Mauritius banking system is dominated by two long-established domestic (MCB and SBM) and two international banking groups (Barclays and HSBC). Of the 18 commercial banks, four large banks serve both the domestic and foreign market, three large foreign banks serve almost exclusively nonresidents, five small and medium banks are focused on nonresidents, but pay increasing attention to the domestic market; the remainder largely serve the domestic market.

Foreign exchange $(F X)$ versus foreign assets and liabilities. FX liabilities are about 121 percent of GDP and FX assets are 172 percent. Of the latter, 153 percent of GDP represent claims on nonresidents (of which 58 percent of GDP — equivalent to almost one-half of FX liabilities - are simply held as balances in banks abroad). FX lending to residents is only 19 percent of GDP (of which 6 percent of GDP is to the GBCs), and many residents have foreign currency earnings (e.g., the tourist sector). Foreign liabilities are much smaller than FX liabilities because the GBCs are considered residents in the monetary statistics. Liabilities to (the deposits of) the GBCs are funds that originate from foreign investors (who wish to invest, e.g., in India) and are temporarily parked in Mauritian banks before transfer abroad. These deposit floats, though flowing through Mauritian banks, are quite stable in aggregate, amounting to some 72 percent of GDP, virtually all in FX, and providing useful short-term FX liquidity to the banking system. FX liabilities to other residents (34 percent of GDP) likely reflect retail deposits of foreign currency earners (e.g., the tourist trade), and nonresident liabilities likely include regional depositors seeking to benefit from the country's financial and political stability.

Risks. The large net foreign asset position (equal to 109 percent of GDP, or 44 percent of GDP if the GBCs are considered non-residents), the long FX position, the large proportion of FX assets held as highly liquid bank deposits abroad, and the limited FX lending to residents all give comfort that the risks should be manageable. Nevertheless, given the sheer magnitudes, close vigilance is warranted. ${ }^{1 /}$

Mautius: Banks Balance Sheet, end-August 2009

\begin{tabular}{|c|c|c|c|c|c|c|c|}
\hline & \multicolumn{3}{|c|}{ Rupees (billion) } & \multicolumn{2}{|c|}{ Share (percent) ${ }^{1 /}$} & \multicolumn{2}{|c|}{ Percent of GDP } \\
\hline & Total & $\begin{array}{c}\text { Foreign } \\
\text { currency }\end{array}$ & $\begin{array}{r}\text { Domestic } \\
\text { currency }\end{array}$ & Total & $\begin{array}{r}\text { which } \\
\text { FC }^{2 l}\end{array}$ & Total & $\begin{array}{r}f \text { which } \\
F^{2 l}\end{array}$ \\
\hline Assets & 736.4 & 480.9 & 255.5 & 100.0 & 65.3 & 263.0 & 171.7 \\
\hline Claim on residents & 307.8 & 52.4 & 255.5 & 41.8 & 7.1 & 109.9 & 18.7 \\
\hline GBCs & 17.6 & 17.5 & 0.1 & 2.4 & 2.4 & 6.3 & 6.2 \\
\hline Other residents & 290.3 & 34.9 & 255.4 & 39.4 & 4.7 & 103.7 & 12.5 \\
\hline Claim on non-residents & 428.5 & 428.5 & 0.0 & 58.2 & 58.2 & 153.0 & 153.0 \\
\hline Liabilities & 736.4 & 338.9 & 397.5 & 100.0 & 46.0 & 263.0 & 121.0 \\
\hline Liabilities on residents & 612.5 & 297.2 & 315.3 & 83.2 & 40.4 & 218.8 & 106.1 \\
\hline GBCs & 202.9 & 202.8 & 0.1 & 27.6 & 27.5 & 72.5 & 72.4 \\
\hline Other residents & 409.7 & 94.4 & 315.3 & 55.6 & 12.8 & 146.3 & 33.7 \\
\hline Liabilities on non-residents ${ }^{3 /}$ & 123.8 & 41.7 & 82.1 & 16.8 & 5.7 & 44.2 & 14.9 \\
\hline
\end{tabular}

Sources: BoM, Monthly Statistical Bulletin, September 2009.

${ }^{1 / P e r c e n t}$ of total assets.

${ }^{2 /}$ Foreign currency.

${ }^{3 /}$ This includes non-resident liabilities and banks borrowings from banks abroad and

from banks abroad for onlending outside Mauritius are assumed denominated in foreign currency.

${ }^{1 /}$ In reviewing developments over the past decade Patrick Imam and Rainer Köhler ("Balance Sheet Vulnerabilities of Mauritius During A Decade of Crises," forthcoming) conclude that from a balance sheet analysis perspective, the macroeconomic vulnerabilities of Mauritius are manageable. 
Table 1. Mauritius: Public Sector Debt Sustainability Framework, 2004-2014

(In percent of GDP, unless otherwise indicated)

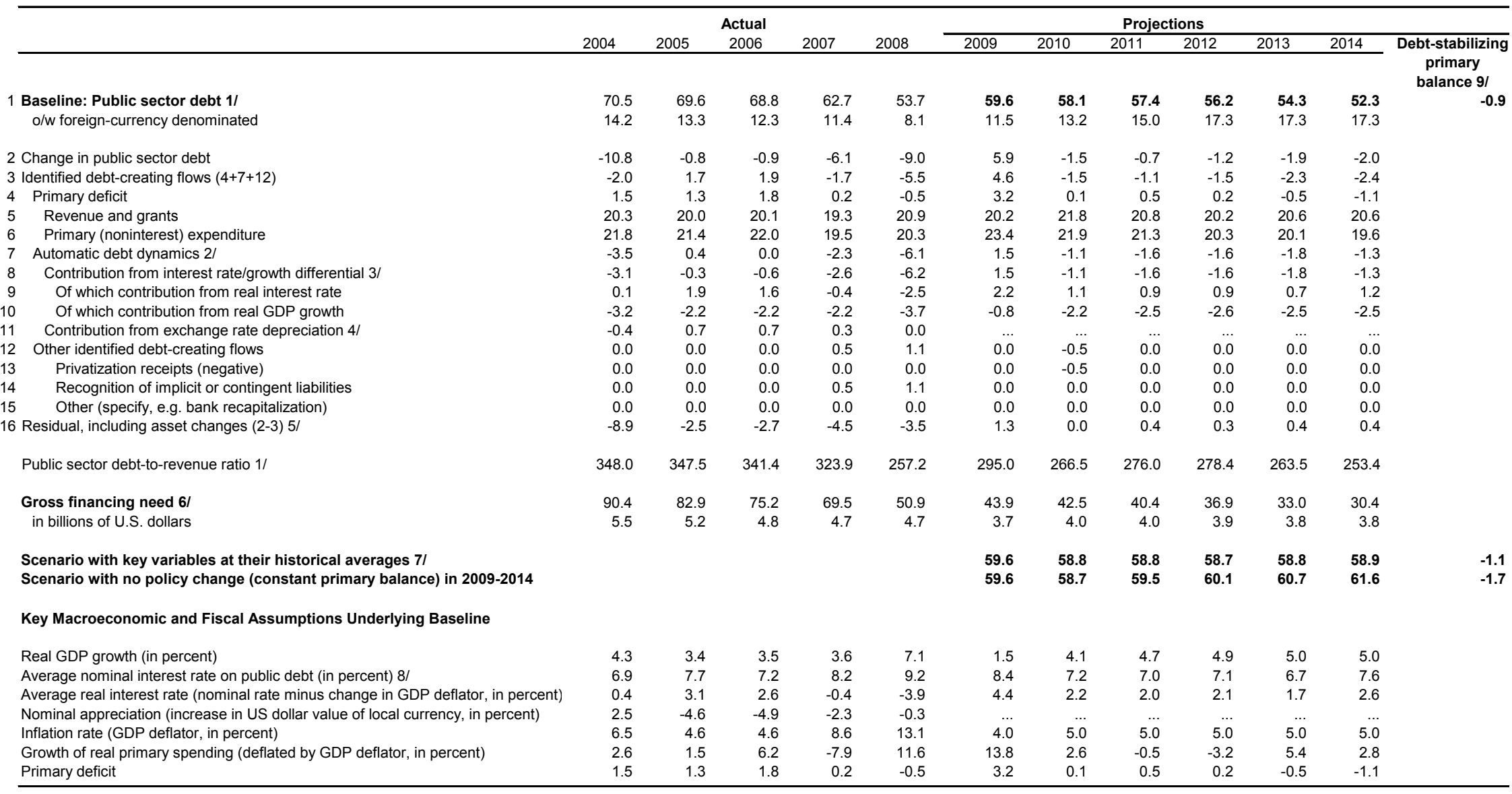

$1 /$ Indicate coverage of public sector, e.g., general government or nonfinancial public sector. Also whether net or gross debt is used.

2/ Derived as $[(r-\pi(1+g)-g+\alpha \varepsilon(1+r)] /(1+g+\pi+g \pi))$ times previous period debt ratio, with $r=$ interest rate; $\pi=$ growth rate of GDP deflator; $g=$ real GDP growth rate; $\alpha=$ share of foreign-currency denominated debt; and $\varepsilon=$ nominal exchange rate depreciation (measured by increase in local currency value of U.S. dollar).

$3 /$ The real interest rate contribution is derived from the denominator in footnote $2 /$ as $r-\pi(1+g)$ and the real growth contribution as $-g$.

$4 /$ The exchange rate contribution is derived from the numerator in footnote $2 /$ as $\alpha \varepsilon(1+r)$.

$6 /$ Defined as public sector deficit, plus amortization of medium and long-term public sector debt, plus short-term debt at end of previous period.

7/ The key variables include real GDP growth; real interest rate; and primary balance in percent of GDP.

8/ Derived as nominal interest expenditure divided by previous period debt stock.

9/ Assumes that key variables (real GDP growth, real interest rate, and other identified debt-creating flows) remain at the level of the last projection year. 
Appendix. Figure 1. Mauritius: Public Sector Debt Sustainability: Bound Tests 1/ (Public debt in percent of GDP)
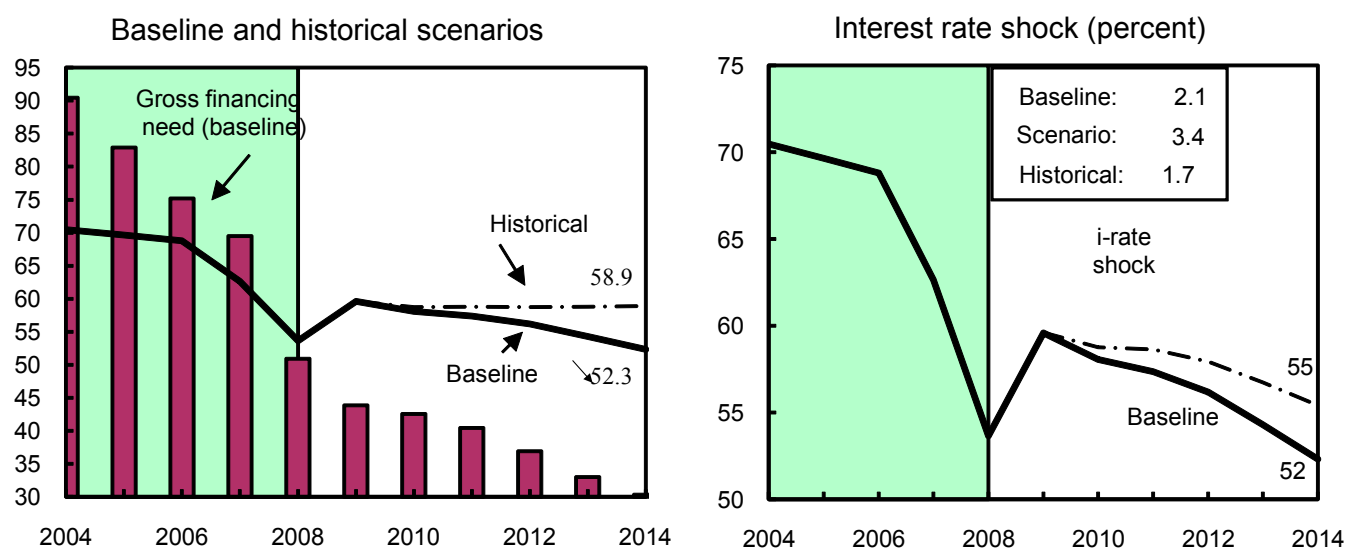

Growth shock (percent per year)

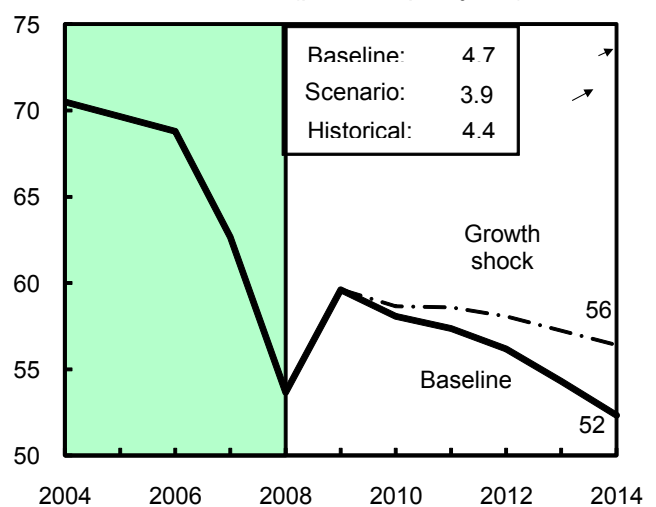

Primary balance shock (percent of GDP) and no policy change scenario (constant primary balance)

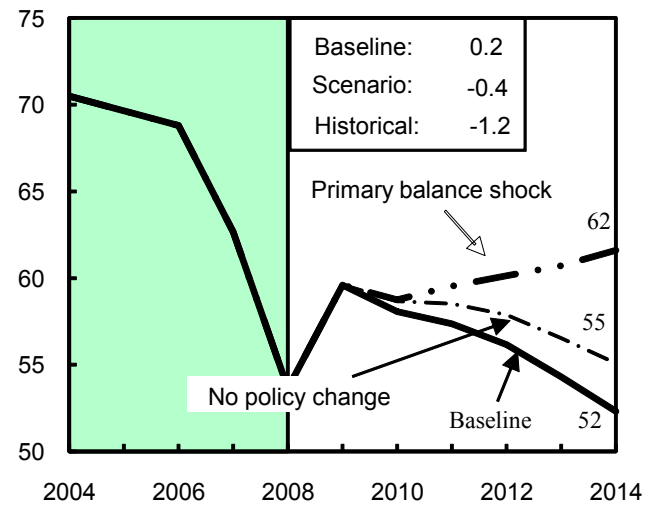

Combined shock 2/

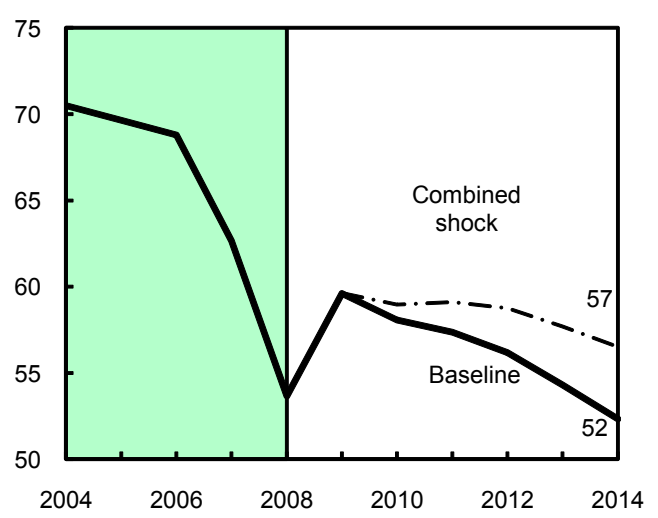

Real depreciation and contingent liabilities shocks 3/

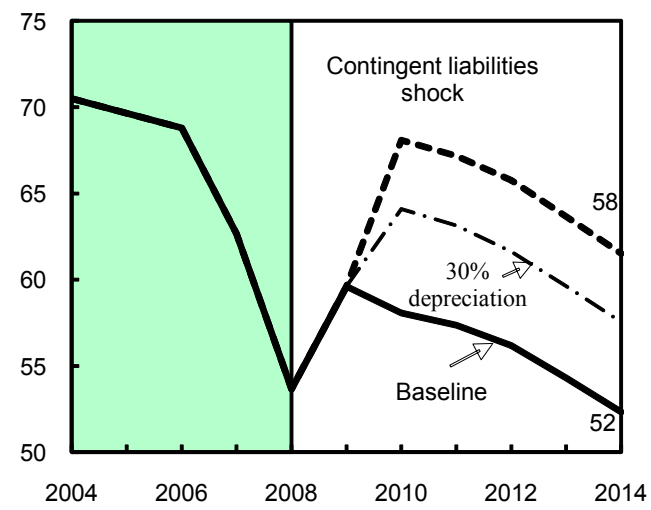

Sources: International Monetary Fund, country desk data, and staff estimates.

$1 /$ Shaded areas represent actual data. Individual shocks are permanent one-half standard deviation shocks. Figures in the boxes represent average projections for the respective variables in the baseline and scenario being presented. Ten-year historical average for the variable is also shown.

2/ Permanent $1 / 4$ standard deviation shocks applied to real interest rate, growth rate, and primary balance.

$3 /$ One-time real depreciation of 30 percent and 10 percent of GDP shock to contingent liabilities occur in 2009, with real depreciation defined as nominal depreciation (measured by percentage fall in dollar value of local currency) minus domestic inflation (based on GDP deflator). 
Table 2. Mauritius: External Debt Sustainability Framework, 2004-2014

(In percent of GDP, unless otherwise indicated)

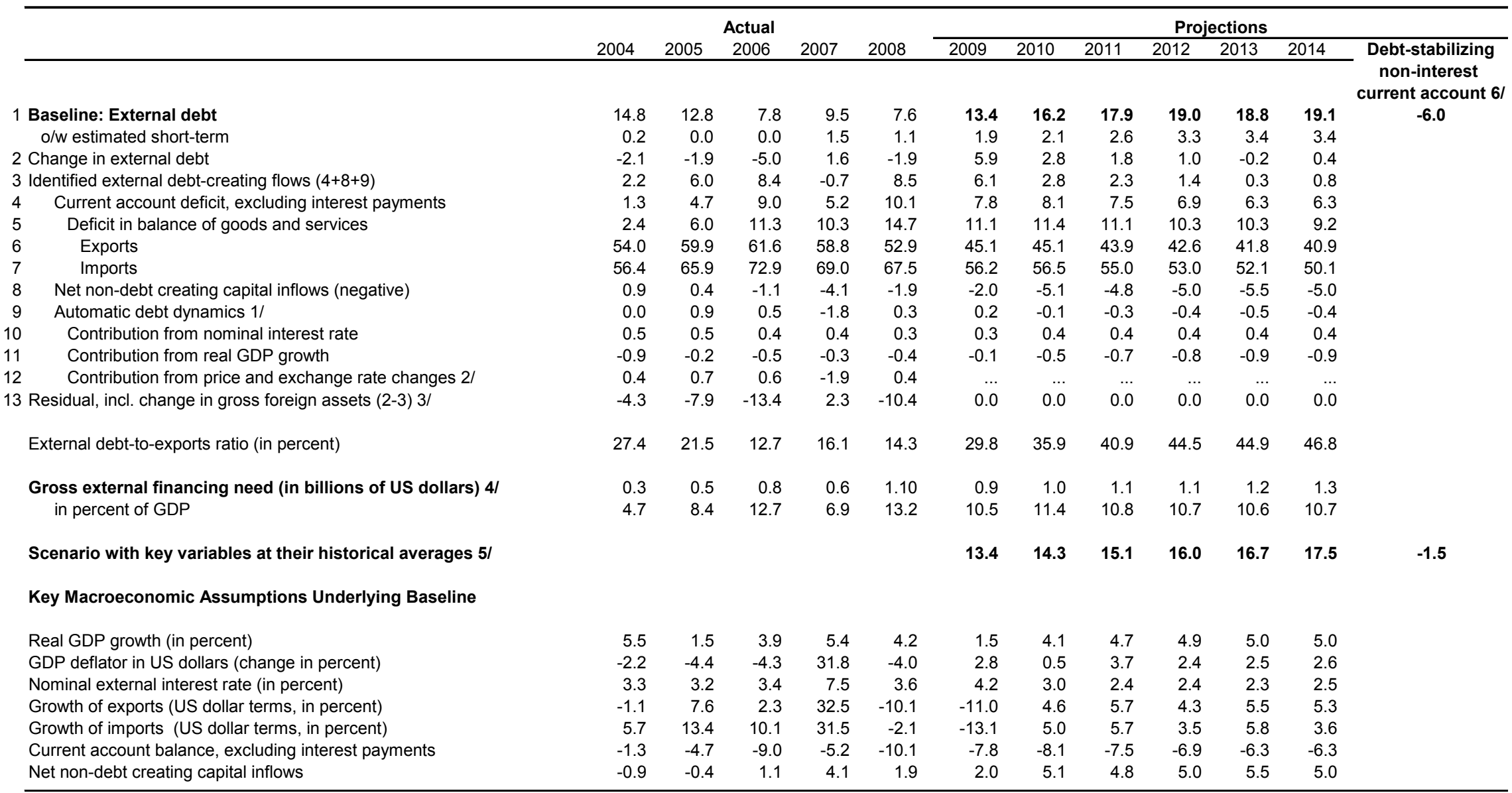

$1 /$ Derived as $[r-g-\rho(1+g)+\varepsilon \alpha(1+r)] /(1+g+\rho+g \rho)$ times previous period debt stock, with $r=$ nominal effective interest rate on external debt; $\rho=$ change in domestic GDP deflator in US dollar terms, $\varepsilon=$ nominal appreciation (increase in dollar value of domestic currency), and $\alpha=$ share of domestic-currency denominated debt in total external debt.

$2 /$ The contribution from price and exchange rate changes is defined as $[-\rho(1+g)+\varepsilon \alpha(1+r)] /(1+g+\rho+g \rho)$ times previous period debt stock.

$3 /$ For projection, line includes the impact of price and exchange rate changes.

4/ Defined as current account deficit, plus amortization on medium- and long-term debt, plus short-term debt at end of previous period

5/ The key variables include real GDP growth; nominal interest rate; dollar deflator growth; and both non-interest current account and non-debt inflows in percent of GDP.

6/ Long-run, constant balance that stabilizes the debt ratio assuming that key variables (real GDP growth, nominal interest rate, dollar deflator growth, and non-debt inflows in percent of GDP) remain at their levels of the last projection year. 
Appendix I. Figure 2. Mauritius: External Debt Sustainability: Bound Tests ${ }^{1 /}$ (External debt in percent of GDP)
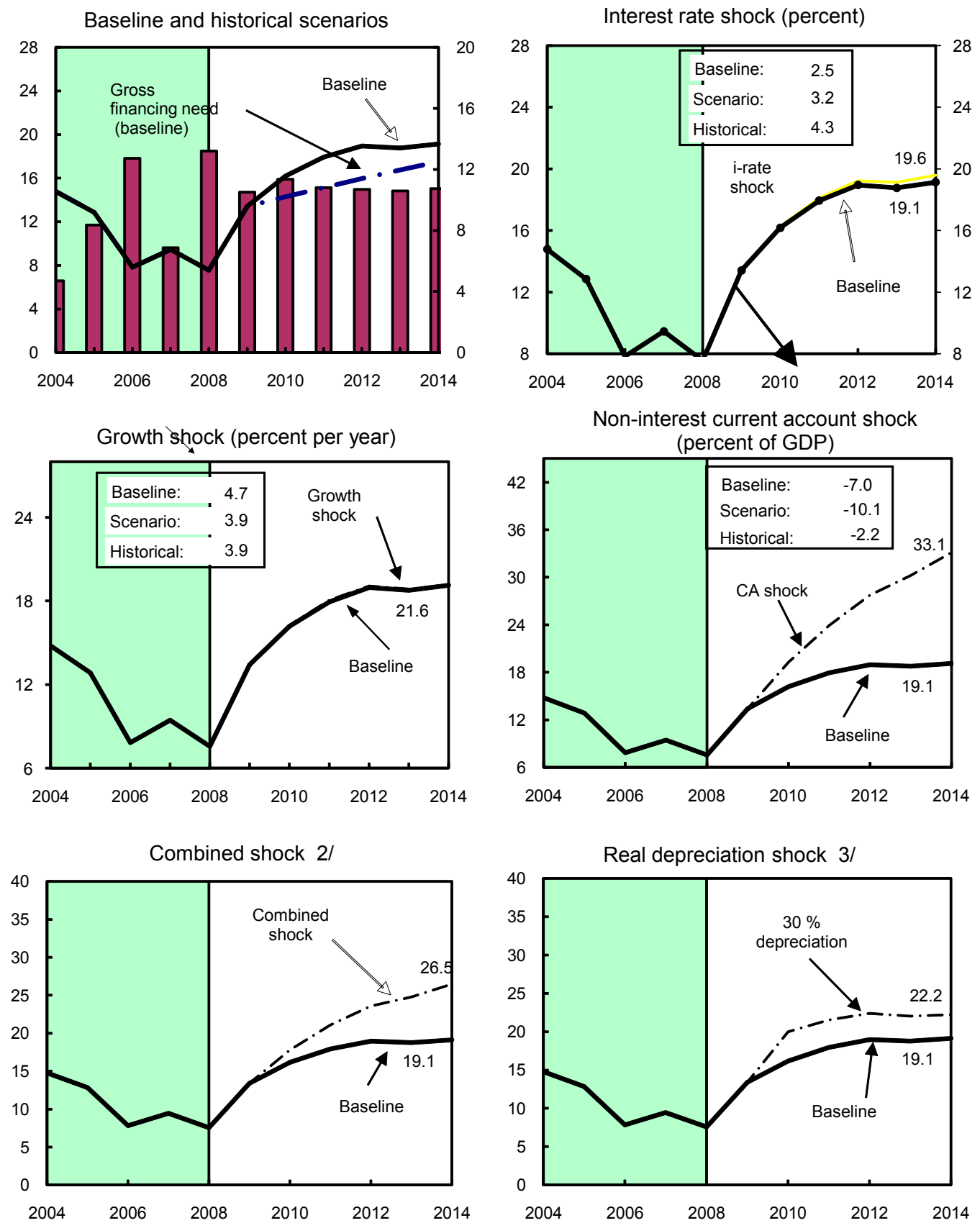

Sources: International Monetary Fund, Country desk data, and staff estimates.

$1 /$ Shaded areas represent actual data. Individual shocks are permanent one-half standard deviation shocks. Figures in the boxes represent average projections for the respective variables in the baseline and scenario being presented. Ten-year historical average for the variable is also shown.

2/ Permanent 1/4 standard deviation shocks applied to real interest rate, growth rate, and current account balance.

3/ One-time real depreciation of 30 percent occurs in 2009. 


\section{INTERNATIONAL MONETARY FUND}

\section{MAURITIUS \\ Staff Report for the 2009 Article IV Consultation Informational Annex}

Prepared by the African Department

Approved by Roger Nord and Aasim Husain

December 28, 2009

- $\quad$ Relations with the Fund. Describes financial and technical assistance by the IMF and provides information on the safeguards assessment and exchange system. Mauritius has no outstanding purchases and loans from the Fund.

- $\quad$ The Joint Management Action Plan (JMAP) Bank-Fund Matrix. Describes the priorities and main activities of the World Bank Group and the IMF and areas of cooperation in their work with the Mauritian authorities.

- Relations with the African Development Bank Group (ADB). Describes the priorities and main activities of the ADB with the Mauritian authorities.

- $\quad$ Statistical Issues. Assesses the quality of statistical data. Economic data for Mauritius are adequate for surveillance. The country is participating in the General Data Dissemination System and is planning to move to the Special Data Dissemination Standard by mid-2010.

I. Relations with the Fund 2

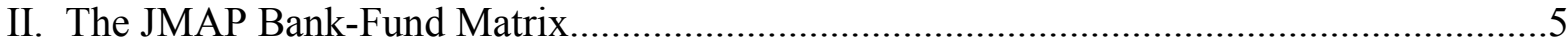

III. Relations with the African Development Bank Group ..............................................

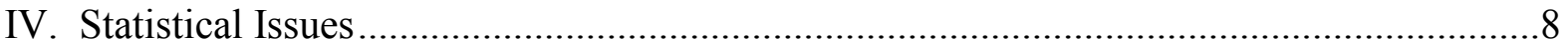




\section{Appendix I. Relations with the Fund}

(As of November 30, 2009)

\section{Membership Status}

Joined on September 23, 1968; Article VIII.

\section{General Resources Account}

Quota

Fund holdings of currency

Reserve position in Fund

III. SDR Department

Net cumulative allocation

Holdings
SDR Million

101.60

88.45

13.15

SDR Million

96.81

99.94
Percent of Quota

$$
100.00
$$

87.05

12.95

Percent of Allocation

100.00

103.23

IV. Outstanding Purchases and Loans

None.

\section{Latest Financial Arrangements}

Amount

Approved Amount Drawn

Type

Approval Date

Expiration Date

$8 / 31 / 86$

$8 / 17 / 84$

$12 / 20 / 82$
(SDR million)

(SDR million)

49.00

49.50

49.00

49.50

30.00 


\section{Projected Payments to Fund ${ }^{1 /}$}

(SDR Million; based on existing use of resources and present holdings of SDRs)

\begin{tabular}{llllll} 
& \multicolumn{4}{c}{ Forthcoming } \\
\cline { 2 - 5 } & $\underline{2009}$ & $\underline{2010}$ & $\underline{2011}$ & $\underline{2012}$ & $\underline{2013}$ \\
Principal & & $\underline{0.01}$ & $\underline{0.01}$ & $\underline{0.01}$ & $\underline{0.01}$ \\
Charges/Interest & & $\underline{0.01}$ & $\underline{0.01}$ & $\underline{0.01}$ & $\underline{0.01}$
\end{tabular}

${ }^{1 /}$ When a member has overdue financial obligations outstanding for more than three months, the amount of such arrears will be shown in this section.

\section{Implementation of HIPC Initiative}

Not applicable.

\section{Implementation of Multilateral Debt Relief Initiative (MDRI)}

Not applicable.

\section{Safeguards Assessments}

Not applicable.

\section{Exchange Rate Arrangement}

At the time of the 2008 Article IV consultations, Mauritius was classified as a managed float exchange rate regime with interventions aimed at smoothening volatility rather than altering the trend. Reflecting the lack of intervention since December 2008, Mauritius' exchange rate regime was reclassified from a managed float to a free float in the Fund's 2009 Annual Report on Exchange Arrangements and Exchange Restrictions. The exchange arrangement is free of multiple currency practices and restrictions on the making of payments and transfers for current international transactions. Mauritius accepted the obligations of Article VIII, Section 2(a), 3, and 4 on September 29, 1993. Mauritius also maintains a liberal capital account. On December 15, 2009, the US\$1 was equivalent to MUR 28.84.

\section{Article IV Consultation}

Mauritius is on the standard 12-month cycle. The last Article IV consultation staff report (Country Report No. 08/238, June 2008) was considered by the Executive Board on July 2, 2008. A Financial System Stability Assessment update was completed by a joint IMF-World Bank team on April 20, 2007. 


\section{Technical Assistance (2004-2009)}

FAD mission on revenue administration and tax policy, February 2004. MFD mission on banking supervision and legislation, October 2004.

MFD mission on banking supervision during 2005: the first mission in January 2005, and the second in March-April 2005.

FAD mission on revenue administration and tax policy, January 2005.

MFD mission on financial sector policy and strategy, January 2006.

FAD mission on fiscal adjustment strategy and Poverty and Social Impact Analysis (PSIA), February-March 2006.

MFD mission on financial sector policy and strategy, July 2006.

MFD mission on banking supervision/monetary operations/monetary policy, October 2006.

STA mission on multisector statistics, November 2006.

MCM mission on financial sector policy and strategy, January 2007.

MCM primary mission on Financial Sector Assessment Program (FSAP), February 2007.

FAD mission on Public Financial Management (PFM) and Medium-Term Expenditure

Framework (MTEF), March 2007.

MCM mission on financial sector policy and strategy, March-April 2007.

STA mission on balance of payments statistics, March 2007.

MCM mission on foreign exchange markets, August 2007.

STA balance of payments module mission, October 2007.

STA mission on Phase II SDSS balance of payments statistics, October-November 2007.

STA Report on the Observance of Standards and Codes (ROSC) mission,

November-December 2007.

FAD mission on Public Financial Management (PFM): Implementing Program-Based

Budgeting: Next Steps, February 2008.

STA mission on national accounts statistics, February 2008.

STA mission on Phase II SDSS Government Finance Statistics, March 2008.

MCM mission on Central Bank-FSAP follow-up, March 2008 (2 missions).

STA mission on Phase II SDSS Multisector Statistics, March-April 2008.

STA mission on monetary and financial statistics, April 2008.

STA mission on balance of payments statistics, May 2009.

FAD mission on refining program budgeting and performance management, Sep 16-24, 2009

STA mission on national accounts statistics, November 10-19, 2009

Resident Representative: None. 


\section{Appendix II. The JMAP Bank-Fund Matrix (2010)}

(As of December 1, 2009)

\begin{tabular}{|c|c|c|c|}
\hline Title & Products & $\begin{array}{l}\text { Provisional timing of } \\
\text { mission }\end{array}$ & $\begin{array}{l}\text { Expected delivery } \\
\text { date }\end{array}$ \\
\hline \multicolumn{4}{|c|}{ A. Mutual Information on Relevant Work Programs } \\
\hline \multirow[t]{8}{*}{ Bank } & $\begin{array}{l}\text { Strategy and analytical work: } \\
\text { The 2007-2013 World Bank Country Partnership } \\
\text { Strategy for Mauritius aims at helping the Government } \\
\text { to deal with (i) short-term trade shocks and (ii) the } \\
\text { transition to a more competitive and diversified } \\
\text { economy, while minimizing negative social impacts } \\
\text { along the transition. Because the Country Partnership } \\
\text { Strategy sets out a broad program, specific activities } \\
\text { are determined every year through the Annual } \\
\text { Business Plan meeting held jointly with the } \\
\text { Government and Development Partners. }\end{array}$ & & \\
\hline & CPS: Country Partnership Strategy (Mid-term review) & Early 2010 & $\begin{array}{l}\text { Board Presentation } \\
\text { in } 2010\end{array}$ \\
\hline & $\begin{array}{l}\text { METAP: Mauritius Economic Transition Technical } \\
\text { Assistance Project }\end{array}$ & $\begin{array}{l}\text { Task team leader in } \\
\text { Mauritius }\end{array}$ & $\begin{array}{l}\text { Approved in } 2009 \\
\text { and disbursing }\end{array}$ \\
\hline & $\begin{array}{l}\text { DPL4: Fourth Trade and Competitiveness } \\
\text { Development Policy Loan (DPL4). Last operation of } \\
\text { the current programmatic series }\end{array}$ & Second semester 2009 & $\begin{array}{l}\text { Loan Signed } \\
\text { December } 2009\end{array}$ \\
\hline & INFRA: Infrastructure Investment Lending & $\begin{array}{l}\text { Supervision missions in } \\
2010\end{array}$ & $\begin{array}{l}\text { Loan Signed } \\
\text { December } 2009\end{array}$ \\
\hline & $\begin{array}{l}\text { MSDCP: Manufacturing and Services Development } \\
\text { and Competitiveness Project (MSDCP) }\end{array}$ & $\begin{array}{l}\text { Supervision mission in } \\
2010\end{array}$ & $\begin{array}{l}\text { Board Presentation } \\
\text { in January } 2010\end{array}$ \\
\hline & $\begin{array}{l}\text { SAFE: Safeguard Diagnostics Review for use of } \\
\text { Mauritius Country Systems in investment projects }\end{array}$ & Completed in 2009 & Completed in 2009 \\
\hline & $\begin{array}{l}\text { PROC: Review of public procurement systems for use } \\
\text { of Mauritius country systems in investment projects }\end{array}$ & November 2009 & June 2010 \\
\hline \multirow[t]{2}{*}{ Fund } & $\begin{array}{l}\text { Work program in the next } 12 \text { months: } \\
-\quad 2010 \text { Article IV consultation }\end{array}$ & Q4 2010 & $\begin{array}{l}\text { Board meeting in } \\
\text { Nov. / Dec. } 2010\end{array}$ \\
\hline & - STA TA in balance of payments statistics & [Q1 2010] & TA report [Q2 2010] \\
\hline
\end{tabular}




\begin{tabular}{|l|l|l|l|}
\hline Title & Products & \multicolumn{1}{|l|}{$\begin{array}{l}\text { Provisional timing of } \\
\text { mission }\end{array}$} & $\begin{array}{l}\text { Expected delivery } \\
\text { date }\end{array}$ \\
\hline \multicolumn{2}{|c|}{ B. Requests for Work Program inputs } & \\
\hline $\begin{array}{l}\text { Bank } \\
\text { request to } \\
\text { Fund }\end{array}$ & None. & & \\
\hline $\begin{array}{l}\text { Fund } \\
\text { request to } \\
\text { Bank }\end{array}$ & None. & & \\
\hline \multicolumn{1}{|c|}{ C. Agreement on Joint Products and Missions } & \\
\hline $\begin{array}{l}\text { Joint } \\
\text { products }\end{array}$ & None. & & \\
\hline
\end{tabular}




\section{Appendix III. Relations with the African Development Bank Group}

(As of December 1, 2009)

Assistance from the African Development Bank (ADB) to Mauritius combines lending and non-lending activities. Lending has focused on infrastructure development in agriculture and transportation and non-lending on economic and sector work (ESW) in health, poverty reduction, and debt management. Under the NEPAD Program, ADB has collaborated with the UNDP, AU, and ECA on the African Peer Review Mechanism (APRM), for which Mauritius is one of the four pilot cases. An ADB study on poverty, gender, and social exclusion is also under preparation and is being coordinated with the EU and the UNDP, while there are studies by the ADB concerning health and sanitation. Past collaboration with the World Bank (and other partners) includes water, sewerage, and sanitation (the Plaines Wilhems Sewerage Project) and transport (Southeastern Highway). A close working relationship has developed between the two institutions during the preparation and appraisal of the first and second Development Policy Loans.

Table 1. Operations Summary as of December 1, 2009

Operations since: 1975

Total Number of operations 35 :

24 Projects, 3 Policy based Operations; 3 Studies; 5 Lines of Credit.

\begin{tabular}{ccccc}
\hline $\begin{array}{c}\text { Source of } \\
\text { financing }\end{array}$ & $\begin{array}{c}\text { Commitments } \\
\text { net }^{1} \\
\text { (UA million) }\end{array}$ & Percentage share & $\begin{array}{c}\text { Disbursed } \\
\text { amount } \\
\text { (UA million) }\end{array}$ & $\begin{array}{c}\text { Percentage } \\
\text { disbursed }^{2}\end{array}$ \\
\hline ADB & $651.95^{3}$ & 98.90 & 162.46 & 24.90 \\
ADF $^{4}$ & 4.26 & 0.60 & 4.26 & 100.00 \\
NTF $^{5}$ & 2.89 & 0.50 & 2.88 & 99.70 \\
Total & 659.10 & 100.00 & 169.6 & 25.70 \\
\hline
\end{tabular}

Questions may be referred to Septime Martin (email: smartin@afdb.org)

\footnotetext{
${ }^{1}$ Out of cancellations amounting UA 168.2 million.

${ }^{2}$ Percentage of commitments net relative to each respective source of financing.

${ }^{3}$ Includes the recent USD420 million and EUR186 million ADB budget loan approval of November 2009.

${ }^{4}$ African Development Fund.

${ }^{5}$ Nigeria Trust Fund.
} 


\section{Appendix IV. Statistical Issues}

\section{MAURITIUS - STATISTICAL ISSUES APPENDIX \\ As of December 15, 2009}

\section{Assessment of Data Adequacy for Surveillance}

General: Data provision is adequate for surveillance. However, balance of payments (BOP) and international investment position (IIP) statistics could be improved to meet SDDS requirements. The authorities are aware of this situation and are continuing work in this regard.

Balance of Payments and International Investment Position Statistics: Coverage and accuracy of BOP and IIP statistics has diminished as a consequence of the liberalization and the growth of global business license holders. Notably, there has been an increase in net errors and omissions in the BOP; while the IIP statistics tend to undercount international liabilities as transactions of offshore financial institutions with the rest of the world are only partially covered. Both factors combine to increase the uncertainty associated with economic analysis of the external sector.

\section{Data Standards and Quality}

Participant in the GDDS since September 2002. The authorities have a time-bound action plan to improve coverage of BOP and IIP statistics that, when completed, should help them be in a position to subscribe to the SDDS by about mid-2010.
A data ROSC report was published in August 2008. 


\section{Mauritius: Table of Common Indicators Required for Surveillance}

December 15, 2009

\begin{tabular}{|c|c|c|c|c|c|c|c|}
\hline & \multirow{2}{*}{$\begin{array}{l}\text { Date of latest } \\
\text { observation }\end{array}$} & \multirow{2}{*}{$\begin{array}{l}\text { Date } \\
\text { received }\end{array}$} & \multirow{2}{*}{$\begin{array}{l}\text { Frequency } \\
\text { of data }^{7}\end{array}$} & \multirow{2}{*}{$\begin{array}{l}\text { Frequency of } \\
\text { reporting }\end{array}$} & \multirow{2}{*}{$\begin{array}{l}\text { Frequency of } \\
\text { publication }^{7}\end{array}$} & \multicolumn{2}{|c|}{ Memo Items: } \\
\hline & & & & & & $\begin{array}{l}\text { Data Quality- } \\
\text { Methodological } \\
\text { soundness }{ }^{8}\end{array}$ & $\begin{array}{c}\text { Data Quality- } \\
\text { Accuracy and } \\
\text { reliability }^{9}\end{array}$ \\
\hline Exchange Rates & December 2009 & $12 / 14 / 2009$ & $\mathrm{D}$ & $\mathrm{D}$ & $\mathrm{D}$ & & \\
\hline $\begin{array}{l}\text { International Reserve Assets and Reserve } \\
\text { Liabilities of the Monetary Authorities }{ }^{1}\end{array}$ & November 2009 & $12 / 2009$ & $\mathrm{M}$ & $\mathrm{M}$ & $\mathrm{M}$ & & \\
\hline Reserve/Base Money & October 2009 & $12 / 10 / 2009$ & $\mathrm{M}$ & $\mathrm{M}$ & $\mathrm{M}$ & \multirow{4}{*}{$\mathrm{O}, \mathrm{LO}, \mathrm{LO}, \mathrm{LO}$} & \multirow{4}{*}{$\mathrm{O}, \mathrm{O}, \mathrm{O}, \mathrm{O}, \mathrm{LO}$} \\
\hline Broad Money & October 2009 & $12 / 10 / 2009$ & M & $\mathrm{M}$ & $\mathrm{M}$ & & \\
\hline Central Bank Balance Sheet & October 2009 & $12 / 10 / 2009$ & M & M & M & & \\
\hline $\begin{array}{l}\text { Consolidated Balance Sheet of the Banking } \\
\text { System }\end{array}$ & October 2009 & $12 / 10 / 2009$ & $\mathrm{M}$ & $\mathrm{M}$ & M & & \\
\hline Interest Rates $^{2}$ & October 2009 & $12 / 10 / 2009$ & M & M & M & & \\
\hline Consumer Price Index & November 2009 & $12 / 7 / 2009$ & $\mathrm{M}$ & $\mathrm{M}$ & $\mathrm{M}$ & $\mathrm{O}, \mathrm{LO}, \mathrm{O}, \mathrm{O}$ & $\mathrm{O}, \mathrm{O}, \mathrm{O}, \mathrm{O}, \mathrm{O}$ \\
\hline $\begin{array}{l}\text { Revenue, Expenditure, Balance and Composition } \\
\text { of Financing }^{3} \text { - General Government }\end{array}$ & Q2/2009 & $11 / 2009$ & Q & Q & Q & \multirow[t]{2}{*}{$\mathrm{LO}, \mathrm{O}, \mathrm{O}, \mathrm{O}$} & \multirow[t]{2}{*}{$\mathrm{LO}, \mathrm{O}, \mathrm{O}, \mathrm{O}, \mathrm{NO}$} \\
\hline $\begin{array}{l}\text { Revenue, Expenditure, Balance and Composition } \\
\text { of Financing }{ }^{3}-\text { Central Government }\end{array}$ & Q2/2009 & $11 / 2009$ & Q & Q & Q & & \\
\hline $\begin{array}{l}\text { Stocks of Central Government and Central } \\
\text { Government-Guaranteed Debt }\end{array}$ & Q2/2009 & $11 / 2009$ & Q & Q & Q & & \\
\hline External Current Account Balance & Q2/2009 & $10 / 2009$ & Q & Q & Q & \multirow[t]{2}{*}{$\mathrm{O}, \mathrm{LO}, \mathrm{LO}, \mathrm{LO}$} & \multirow{2}{*}{$\begin{array}{l}\text { LNO, LNO, LO, } \\
\text { LO, NO }\end{array}$} \\
\hline Exports and Imports of Goods and Services & Q2/2009 & $10 / 2009$ & Q & Q & Q & & \\
\hline
\end{tabular}




\begin{tabular}{|c|c|c|c|c|c|c|c|}
\hline & \multirow{2}{*}{$\begin{array}{c}\text { Date of latest } \\
\text { observation }\end{array}$} & \multirow{2}{*}{$\begin{array}{c}\text { Date } \\
\text { received }\end{array}$} & \multirow{2}{*}{$\begin{array}{l}\text { Frequency } \\
\text { of data }^{7}\end{array}$} & \multirow{2}{*}{$\begin{array}{c}\text { Frequency of } \\
\text { reporting }^{7}\end{array}$} & \multirow{2}{*}{$\begin{array}{l}\text { Frequency of } \\
\text { publication }^{7}\end{array}$} & \multicolumn{2}{|c|}{ Memo Items: } \\
\hline & & & & & & $\begin{array}{l}\text { Data Quality- } \\
\text { Methodological } \\
\text { soundness }{ }^{8}\end{array}$ & $\begin{array}{c}\text { Data Quality- } \\
\text { Accuracy and } \\
\text { reliability }\end{array}$ \\
\hline GDP/GNP & Q2/2009 & $10 / 2009$ & Q & A & A & $\mathrm{O}, \mathrm{LO}, \mathrm{O}, \mathrm{LO}$ & $\begin{array}{c}\mathrm{LO}, \mathrm{O}, \mathrm{LNO}, \mathrm{LO}, \\
\mathrm{O}\end{array}$ \\
\hline Gross External Debt & Q2/2009 & $10 / 2009$ & Q & Q & Q & & \\
\hline International Investment Position $^{6}$ & Q4/2008 & $06 / 2009$ & Q & Q & Q & & \\
\hline
\end{tabular}

${ }^{1}$ Any reserve assets that are pledged of otherwise encumbered should be specified separately. Also, data should comprise short-term liabilities linked to a foreign currency but settled by other means as well as the notional values of financial derivatives to pay and to receive foreign currency, including those linked to a foreign currency but settled by other means.

${ }^{2}$ Both market-based and officially determined, including discount rates, money market rates, rates on treasury bills, notes, and bonds.

${ }^{3}$ Foreign, domestic bank, and domestic nonbank financing.

${ }^{4}$ The general government consists of the central government (budgetary funds, extra budgetary funds, and social security funds) and state and local governments.

${ }^{5}$ Including currency and maturity composition.

${ }^{6}$ Includes external gross financial asset and liability positions vis-à-vis nonresidents.

${ }^{7}$ Daily (D); Weekly (W); Monthly (M); Quarterly (Q); Annually (A); Irregular (I); Not Available (NA).

${ }^{8}$ Reflects the assessment provided in the data ROSC published in August, 2008, and based on the findings of the mission that took place during November 29-December 7, 2007 for the dataset corresponding to the variables in each row. The assessment indicates whether international standards concerning concepts and definitions, scope, classification/sectorization, and basis for recording are fully observed (O), largely observed (LO), largely not observed (LNO), or not observed (NO).

${ }^{9}$ Same as footnote 8 , except referring to international standards concerning source data, assessment and validation of source data, statistical techniques, assessment and validation of intermediate data and statistical outputs, and revision studies. 
Public Information Notice (PIN) No. 10/13

FOR IMMEDIATE RELEASE

January 26, 2010
International Monetary Fund

$70019^{\text {th }}$ Street, NW

Washington, D. C. 20431 USA

\section{IMF Concludes 2009 Article IV Consultation with Mauritius}

On January 13, 2010, the Executive Board of the International Monetary Fund (IMF) concluded the Article IV consultation with Mauritius. ${ }^{1}$

\section{Background}

Economic growth has slowed sharply in the wake of the global financial crisis, but is expected to rebound next year. Output growth slowed from 4.2 per year percent in 2008 to less than 2 percent in 2009 as key drivers of growth (tourism, textiles, and construction) contracted. Inflation has fallen to the low single digits as a result of lower global food and commodity prices and the slowdown of the domestic economy. The current account deficit has narrowed as lower imports have more than offset the contraction of external demand.

The authorities' policy response was commendably prompt and comprehensive, including a fiscal stimulus package of some 5 percent of GDP over the period July 2009-December 2010. The package is well-targeted and temporary, intended to cushion the economy against the impact of the crisis. The government was prescient in having saved some 3 percent of GDP in special funds against such a rainy day. For its post-crisis strategy, the key challenge will be to resume fiscal consolidation without jeopardizing the recovery. Given the uncertain outlook, the government has rightly decided to keep some stimulus measures contingent; the 2010 deficit is now expected to be $4 \frac{1}{2}$ percent of GDP. Further fiscal consolidation of public debt is important to reduce risks inherent to a relatively high level of

1 Under Article IV of the IMF's Articles of Agreement, the IMF holds bilateral discussions with members, usually every year. A staff team visits the country, collects economic and financial information, and discusses with officials the country's economic developments and policies. On return to headquarters, the staff prepares a report, which forms the basis for discussion by the Executive Board. At the conclusion of the discussion, the Managing Director, as Chairman of the Board, summarizes the views of Executive Directors, and this summary is transmitted to the country's authorities. This PIN summarizes the views of the Executive Board as expressed during the May 2008 Executive Board discussion based on the staff report. 
public debt. Forward-looking debt sustainability analyses show that public and external debt should remain sustainable over the medium term. The 2008 Public Debt Management Act will serve to instill fiscal discipline and help ensure debt remains sustainable.

With inflationary pressures subdued, and the economic outlook uncertain, the monetary policy stance appears appropriate. In the wake of the crisis, the Monetary Policy Committee of the Bank of Mauritius (BoM) reduced the key Repo rate to 5.75 percent per year in successive steps and has kept it unchanged over the past few months pending further indication of the state of the economy. The BoM has refrained from intervention since December 2008, and the floating exchange rate has remained stable against the U.S. dollar.

The Mauritian banking system has withstood the impact of the global financial turmoil. Banks' conservative business practices, their strong initial balance sheets, and the "Mauritius Approach"-providing temporary financial relief to firms hit by the crises-have kept the financial system sound. Capital adequacy, liquidity, and profitability of the banking system remain sound, and the system appears resilient.

Measures to enhance efficiency in the public sector and to meet SDDS subscription requirements are well under way. Labor market reforms have been enacted, and service delivery and efficiency of the public sector is improving, especially in regard to social protection. The authorities are on track to improve the coverage of external statistics and to apply for SDDS subscription by mid-2010.

The medium-term growth forecast remains benign, but there is significant uncertainty because Mauritius' growth prospects depend heavily on the global economy. Economic growth is projected to increase to 5 percent per year by 2011, reflecting a reversal of the growth contraction in the EU, Mauritius' main market for exports and tourism. But further deterioration of the external accounts cannot be ruled out if global demand remains sluggish and capital inflows dry up. And if world demand does begin to pick up too rapidly, there is a risk that a surge in oil prices could more than offset a rebound in demand for Mauritian exports, causing a deterioration of the trade deficit, larger financing requirements, and inflationary pressures.

\section{Executive Board Assessment}

Executive Directors commended the Mauritian authorities for their prompt and comprehensive policy response, which has been instrumental in cushioning the economy from the fallout of the global financial crisis. The size of the targeted and temporary fiscal stimulus package, and the extent of the monetary easing, were well-calibrated to the magnitude of the external shock. Directors commended the authorities' implementation of far-reaching reforms in recent years and their track record of strong policy responses to unexpected shocks.

Given the uncertain outlook, and the challenge of resuming fiscal consolidation without jeopardizing the recovery, Directors supported the authorities' decision to keep some stimulus measures in reserve, to be deployed only if the economy falters. While agreeing on the accommodative fiscal stance, Directors underscored that fiscal consolidation remains important for reducing the vulnerabilities inherent in a still-relatively high level of public debt, as well as for narrowing the current account deficit. Although immediate financing risks 
appear limited, reducing public debt further will help create fiscal space for meeting contingencies and the eventual costs of an aging population. In this context, Directors noted that the recent public debt management law will strengthen fiscal discipline and help ensure medium-term sustainability.

Directors welcomed the authorities' efforts to secure external financing while underscoring that this financing should not widen the deficit. They supported the authorities' intention to adopt a pragmatic combination of using external financing to the extent it corresponds to capital imports for public investment, limiting the substitution of domestic borrowing to what the market can absorb, and treating part of the external funds as precautionary.

Directors viewed the monetary and exchange rate framework as well-suited to the needs of the Mauritian economy. They encouraged the authorities to take advantage of the currently low inflationary pressures to help anchor inflationary expectations at a lower rate than previously. In this vein, Directors supported the authorities' intention to compile additional high-frequency indicators as well as to further develop analytical tools to better understand inflation dynamics and monetary policy transmission.

Directors noted that, despite the slowdown, the Mauritian banking system remains wellcapitalized and appears resilient. They welcomed the move towards greater risk-based financial sector supervision and looked forward to the early implementation of the remaining recommendations of the 2007 FSAP.

Directors supported the recent improvements in service delivery and efficiency in the public sector, particularly with regard to the social protection system. They called for further efforts to rationalize social assistance to target the poor and to empower people to seize new labor market opportunities.

Directors considered that the key objectives for the medium term are to reduce further the level of public debt, refine the monetary policy framework, and sustain financial sector and structural reforms. Achieving these objectives would raise productivity, further improve the economy's resilience, and better position Mauritius to compete with other emerging market economies, including as a financial center. Directors also supported the authorities' efforts in pressing forward with data improvements, including to the balance of payments, so as to meet the SDDS requirements by mid-2010.

Directors welcomed the establishment of the new Fund regional technical assistance center, AFRITAC South, in Mauritius.

Public Information Notices (PINs) are issued, (i) at the request of a member country, following the conclusion of the Article IV consultation for countries seeking to make known the views of the IMF to the public. This action is intended to strengthen IMF surveillance over the economic policies of member countries by increasing the transparency of the IMF's assessment of these policies; and (ii) following policy discussions in the Executive Board at the decision of the Board. 
Mauritius: Selected Economic and Financial Indicators, 2005-2013

\begin{tabular}{|c|c|c|c|c|c|c|c|c|c|}
\hline & 2005 & 2006 & 2007 & 2008 & 2009 & 2010 & 2011 & 2012 & 2013 \\
\hline & & & & & \multicolumn{5}{|c|}{ Projections } \\
\hline & \multicolumn{9}{|c|}{ (Annual percent change, unless otherwise indicated) } \\
\hline \multicolumn{10}{|l|}{ National income, prices and employment } \\
\hline \multicolumn{10}{|l|}{ Real GDP } \\
\hline Market prices & 1.5 & 3.9 & 5.4 & 4.2 & 1.5 & 4.1 & 4.7 & 4.9 & 5.0 \\
\hline Factor costs & 2.4 & 5.2 & 5.5 & 5.2 & 2.7 & 4.1 & 4.7 & 5.1 & 5.2 \\
\hline Real GDP per capita & 0.7 & 3.2 & 4.7 & 3.3 & 0.7 & 3.3 & 4.0 & 4.2 & 4.3 \\
\hline GDP deflator & 4.0 & 7.2 & 8.3 & 8.1 & 4.0 & 5.0 & 5.0 & 5.0 & 5.0 \\
\hline Domestic demand at current prices ${ }^{2}$ & 13.0 & 17.8 & 14.2 & 12.2 & 7.8 & 9.5 & 8.4 & 7.2 & 9.3 \\
\hline Consumer prices (period average) & 4.9 & 9.0 & 8.8 & 9.7 & 3.0 & 4.3 & 4.2 & 4.2 & 4.2 \\
\hline Consumer prices (end of period) & 3.9 & 11.8 & 8.7 & 6.8 & 4.0 & 3.0 & 4.9 & 4.5 & 4.1 \\
\hline Unemployment rate (percent) & 9.6 & 9.1 & 8.5 & 7.2 & $\ldots$ & $\ldots$ & $\ldots$ & $\ldots$ & $\ldots$ \\
\hline \multicolumn{10}{|l|}{ External sector } \\
\hline Exports of goods, f.o.b. & 7.3 & 8.9 & -4.7 & 7.3 & -23.5 & 7.2 & 3.1 & 3.6 & 2.9 \\
\hline Of which: tourism receipts & 2.2 & 15.6 & 29.0 & 11.5 & -24.4 & 5.1 & 5.0 & 7.1 & 9.1 \\
\hline Real effective exchange rate (annual averages) & -3.8 & -0.7 & 1.2 & 13.0 & 4.1 & $\ldots$ & $\ldots$ & $\ldots$ & $\ldots$ \\
\hline Terms of trade & -8.4 & -5.8 & -1.0 & -1.1 & 1.6 & $\ldots$ & $\cdots$ & $\cdots$ & ... \\
\hline & \multicolumn{9}{|c|}{ (Annual change in percent of beginning of period M2, unless otherwise indicated) } \\
\hline \multicolumn{10}{|l|}{ Money and credit ${ }^{2}$} \\
\hline Net foreign assets & 6.9 & 48.8 & 13.1 & 8.1 & 3.7 & 13.7 & 6.9 & 7.0 & 7.1 \\
\hline Domestic credit & 14.7 & 10.2 & 11.7 & 22.5 & 8.9 & 14.6 & 12.9 & 13.6 & 13.3 \\
\hline Net claims on government & 1.6 & 0.5 & -0.3 & 0.6 & -1.3 & 4.9 & 0.3 & -0.4 & 0.2 \\
\hline Credit to private sector ${ }^{3}$ & 13.0 & 9.7 & 12.0 & 21.9 & 10.3 & 9.6 & 12.6 & 14.0 & 13.2 \\
\hline Broad money (end of period, annual percentage change) & 11.1 & 9.5 & 15.3 & 14.7 & 12.5 & 13.3 & 9.3 & 9.6 & 9.6 \\
\hline Income velocity of broad money & 0.9 & 0.9 & 0.9 & 0.9 & 1.0 & 1.0 & 1.0 & 1.0 & 1.0 \\
\hline Interest rate (weighted average TBs, primary auctions) & 6.4 & 7.5 & 11.0 & 7.4 & 4.8 & $\ldots$ & $\ldots$ & $\ldots$ & $\ldots$ \\
\hline & \multicolumn{9}{|c|}{ (Percent of GDP) } \\
\hline \multicolumn{10}{|l|}{ Central government budget } \\
\hline Overall balance (including grants) & -5.3 & -4.6 & -4.0 & -3.4 & -4.5 & -4.5 & -3.9 & -3.0 & -2.2 \\
\hline Expenditure and net lending & 25.8 & 23.6 & 25.7 & 26.1 & 25.6 & 25.9 & 24.7 & 23.1 & 22.7 \\
\hline Domestic debt of central government & 51.4 & 46.6 & 45.6 & 43.8 & 42.6 & 41.4 & 38.5 & 34.2 & 31.1 \\
\hline External debt of central government & 4.4 & 6.1 & 4.6 & 6.1 & 8.0 & 8.8 & 11.0 & 13.6 & 13.9 \\
\hline \multicolumn{10}{|l|}{ Investment and saving } \\
\hline Gross domestic investment & 21.4 & 24.3 & 25.1 & 24.6 & 26.3 & 26.2 & 24.6 & 24.6 & 24.8 \\
\hline Public & 7.5 & 6.9 & 6.4 & 5.0 & 6.1 & 7.6 & 6.5 & 7.0 & 7.4 \\
\hline Private & 14.0 & 17.3 & 18.7 & 19.6 & 20.2 & 18.5 & 18.1 & 17.6 & 17.4 \\
\hline Gross national savings & 17.4 & 17.1 & 21.2 & 16.7 & 14.2 & 14.3 & 16.8 & 18.8 & 21.5 \\
\hline Public & -1.5 & -1.1 & -0.5 & -1.1 & -1.1 & -0.8 & -0.7 & 0.4 & 1.3 \\
\hline Private & 18.8 & 18.2 & 21.7 & 17.9 & 15.3 & 15.1 & 17.5 & 18.4 & 20.1 \\
\hline \multicolumn{10}{|l|}{ External sector } \\
\hline Balance of goods and services & -6.0 & -11.3 & -10.3 & -14.7 & -11.1 & -11.4 & -11.1 & -10.4 & -10.3 \\
\hline Exports of goods and services, f.o.b. & 59.9 & 61.6 & 58.8 & 52.9 & 45.1 & 45.2 & 44.2 & 43.1 & 41.8 \\
\hline Imports of goods and services, f.o.b. & -65.9 & -72.9 & -69.0 & -67.5 & -56.2 & -56.6 & -55.3 & -53.5 & -52.1 \\
\hline Current account balance & -5.2 & -9.4 & -5.6 & -10.4 & -8.1 & -8.5 & -8.0 & -7.5 & -6.9 \\
\hline Overall balance & -2.6 & -2.2 & 5.9 & 1.7 & 5.4 & 0.0 & 1.5 & 0.6 & 0.9 \\
\hline Total external debt ${ }^{4}$ & 13.9 & 12.7 & 11.4 & 12.0 & 13.8 & 12.2 & 15.9 & 18.0 & 17.3 \\
\hline Net international reserves, BOM (millions of U.S. dollars) & 1,361 & 1,297 & 1,814 & 1,784 & 1,989 & 2,039 & 2,088 & 2,152 & 2,375 \\
\hline Net international reserves, BOM (months of imports of goods, c.i.f.) & 5.2 & 4.3 & 5.6 & 4.6 & 6.6 & 6.6 & 6.5 & 6.4 & 6.7 \\
\hline \multicolumn{10}{|l|}{ Memorandum item: } \\
\hline GDP at current market prices (millions of Mauritian rupees) & 185,349 & 206,328 & 235,519 & 265,196 & 280,264 & 305,219 & 334,500 & 367,400 & 408,760 \\
\hline GDP at current market prices (millions of U.S. dollars) & 6,284 & 6,507 & 7,521 & 9,321 & 8,527 & $\ldots$ & $\ldots$ & $\ldots$ & $\ldots$ \\
\hline Foreign currency long-term debt rating (Moody's) & Baa2 & Baa1 & Baa2 & Baa2 & $\ldots$ & $\ldots$ & $\ldots$ & $\ldots$ & $\ldots$ \\
\hline
\end{tabular}

Sources: Bank of Mauritius; Central Statistics Office; Ministry of Finance and Empowerment; Moody's; and IMF staff estimates and projections.

${ }^{1}$ Excluding changes in stocks.

2 Percent of beginning of period M2. End-2009 data refer to June.

${ }^{3}$ Includes credit to parastatals.

${ }^{4}$ Reported debt only, excluding private sector short-term debt. 


\section{Statement by Laurean W. Rutayisire, Executive Director for Mauritius January 13, 2010}

\section{I - Introduction}

On behalf of my Mauritian authorities, I would like to express our appreciation to staff for the constructive discussions on the Mauritian economy held during the last Article IV consultation. My authorities are in broad agreement with staff analysis and policy recommendations regarding the challenges facing the economy. They also thank staff for the two working papers issued along side with the 2009 Article IV consultation report. In the context of timely Fund's technical assistance to Mauritius, my authorities value the background provided by staff on common and best practices for the functioning of Monetary Policy Committees and Central Banks' governance structures.

In addition, my Mauritian authorities would like to express their deep appreciation to Fund Management for its decision to locate AFRITAC South in Mauritius. They welcome this decision, which honors Mauritius, and helps translate the IMF's commitment to further contribute to regional member countries' efforts to improve their institutional and human capacity.

My Mauritian authorities are grateful to Staff, Management and the Board for the continued support to their efforts to implement far-reaching reforms initiated in 2006, with a view to restructure the economy and find new drivers for a strong and sustained economic growth. This support, together with the assistance from other partners, has helped Mauritius to earn from the World Bank in 2008 and 2009 the title of the "best place to do business in Africa".

\section{II - Recent Macroeconomic Developments}

The Mauritian economy has not been spared by the global economic slowdown over the past two years in the wake of the financial crisis that erupted in 2007. The economic growth slowed from 4.2 percent in 2008 to 1.5 percent in 2009 , due to the contraction in the sectors of tourism, textile and construction. The activity's contraction in these sectors has led the unemployment rate to reach 8 percent. Export and import volumes are expected to fall respectively by 11.6 percent and 12.8 percent in 2009, mostly because of the economic slowdown in the European Union, which is Mauritius's main trading partner. The current account deficit is expected to narrow by 2.3 percent, given the fact that external demand has been more than offset by reduced imports. However, in sharp decline, FDI has substantially financed the current account deficit. Inflation has fallen to low single digit in 2009, as a result of the contraction of domestic activity and the decline in global food and commodities prices.

In order to overcome the adverse effects of the global crisis on the Mauritian economy, my authorities have designed and implemented prompt and comprehensive policy measures consisting largely of fiscal stimulus, monetary easing, providing foreign exchange liquidity, strengthening the social safety net as well as measures to preserve jobs. The well-targeted fiscal stimulus of about 5 percent of GDP and covering 2009-2010 has been instrumental in helping the economy to weather the global crisis. In the context of the fiscal stimulus, my 
authorities introduced measures to ensure fiscal discipline, with a view to bring the primary budget into surplus by the end of 2011. In their efforts to reduce the current debt financing needs, they have drawn funds from the special rainy day account established in previous financial years. Moreover, they have passed a public debt management act limiting the public sector debt to 60 percent of GDP with a goal of reaching 50 percent by 2013 .

My Mauritian authorities are mindful of the uncertainties attached to the economic outlook, given the heavy dependence of growth prospects on the recovery of the global economy. They are also of the view that the key challenge under the post-crisis strategy is to resume efforts towards fiscal consolidation together with economic recovery. Against this background, they have decided to maintain some stimulus measures up to end of 2010. The 2008 Public debt management Act will facilitate resuming fiscal discipline and ensuring debt sustainability. My authorities remain strongly committed to pursue their reform agenda, with a view to transform the Mauritian economy into an innovative and skill-based services economy.

\section{III - Macroeconomic Policies and Reforms}

\section{Fiscal Policy}

The authorities intend to pursue over the short-term accommodative fiscal stance, which would be phased out as the economy recovers. In this regard, the fiscal stimulus put in place will continue through 2010. The fiscal deficit is projected to be 4.5 percent in 2010 and decline to 4 percent in 2011 and 3 percent in 2013. The framework created by the new public debt law will help strengthen fiscal discipline and ensure medium-term sustainability. Given the uncertainties related to the external environment and the need to pursue infrastructure investment that is critical to further enhancing productivity, the authorities have secured significant financing from donors, including the World Bank and the African Development Bank equivalent to 7 percent of GDP. Mindful of the limits to the substitutability between domestic and external financing of the budget, the authorities intend to treat part of these funds as precautionary and will adopt a pragmatic approach in the use of external financing. To this end, external financing will correspond to capital imports for public investment and the substitution of domestic borrowing will be limited to what the market could absorb.

\section{Monetary Policy}

In response to the economic slowdown due to the crisis, the authorities have implemented bold and appropriate measures on the monetary front. These measures include the reduction of the Central Bank's policy rate by 250 basis points to 5.75 percent and the lowering of the reserve requirements. Moreover, a foreign exchange credit facility was established to ensure liquidity, while preserving reserves. Though the inflationary pressures are subdued, the authorities remain vigilant, given the uncertainties of the global economic outlook and the need to restore a sustained domestic economic activity. The repo rate will be kept at its current level until there are clear indications that the external and domestic environments have improved. With regard to inflation, my authorities concur with staff that the currently low rate may be an opportunity to anchor low inflationary expectations. In this regard, they 
request a technical assistance from the Fund to help develop appropriate econometric models. The flexibility of the floating exchange rate regime has served the economy well. On the move to a formal inflation targeting, the authorities are of the view that much needs to be done, in order to meet the required conditions for such a move.

\section{Financial Sector}

The Mauritian financial sector has withstood the impact of the global financial turmoil, due in particular to its strong initial balance sheets and the temporary financial relief measures provided to firms hit by the crises. Capital adequacy, liquidity and profitability of the banking system remain sound. Significant progress has been made since the 2007 FSAP update. In this context, most of the recommendations of the 2007 Basel Core principles assessment have been implemented. Moreover, the authorities have strengthened the banking supervision, with a view to move towards greater risk-based financial sector supervision. In this regard, the banking supervision has been restructured and most of the guidelines have been revised. The authorities are committed to speed up their efforts to implement the remaining recommendations of the 2007 FSAP. They have also requested a technical assistance from the Fund to help design a deposit insurance scheme in compliance with the Bank of Mauritius 2004 Act and the Banking Act.

\section{Structural Reforms}

Mauritius has made significant inroads in implementing the needed structural reforms to take full opportunity of globalization, bolstering competitiveness, and encouraging the diversification of the economy following the phasing out of trade preferences for textiles and sugar. In this context, regulation related in particular to labor, solvency debt management and procurement legislation has been revamped. A new Employment Rights Bill containing workforce provisions and introducing a "flexi-security" scheme as part of the broader reform of the Industrial Relations Framework is being implemented. This scheme aims at lowering resistance to structural change and will help stabilize incomes for households to allow for greater labor market efficiency.

While pursuing structural reforms and achieving a coherent approach in social security, the authorities have made progress in improving the public sector's efficiency. This approach includes the establishment in July 2008 of a National Empowerment Foundation. Operating under the aegis of the Ministry of Finance and Economic Empowerment, this Foundation covers a wide range of interventions including training, placement, support for small and medium-sized enterprises, and direct financial assistance to vulnerable groups and housing as well. Under the Fund and World Bank assistance, the authorities intend to pursue parastatal reforms to further improve delivery and efficiency in the public sector.

\section{Improvement of External Statistics}

The authorities remain strongly committed to improving the external statistics through intensified efforts to resolve discrepancies in the balance of payments. A joint committee made up of Bank of Mauritius, Financial Services Commissions and the Ministry of Finance and Economic Empowerment has been established to conduct a survey of resident of Global 
Business Companies with a view to enhance the coverage of BoP statistics and the international investment position. In addition, the Mauritian authorities intend to apply for subscription to the Special Data Dissemination Standard (SDDS), which will help strengthen the Mauritius' competitiveness.

\section{IV - Conclusion}

Policy measures implemented by the Mauritian authorities over the recent years have helped to cushion the economy from the impact of the global financial turmoil. In order to maintain a good track record and respond promptly to unexpected shocks, my authorities are mindful of the need to pursue their reform agenda designed to further reduce public debt levels, sustain the diversification of the economy, and improve its competitiveness. In this regard, my authorities will continue to look for a closer relationship with the Fund to assist them in their effort to better design and implement the appropriate policies to meet their ongoing challenges. 